\title{
TUŽBA ZBOG PROPUSTA DONOŠENJA OPĆEG AKTA U EUROPSKOM I HRVATSKOM PRAVU
}

UDK: $349: 502.3$

DOI: $10.31141 /$ zrpfs.2020.57.135.127

Izvorni znanstveni rad

Primljeno: 15. studenog 2019.

U radu se istražuje način na koji bi se, sukladno presudi Suda Europske unije u predmetu C-237/07 Janecek, mogla osigurati sudska zaštita zbog propusta donošenja akcijskih planova za poboljšanje kvalitete zraka koji su prema svojoj pravnoj prirodi opći akti. U prvom i drugom dijelu rada prikazuju se komparativna iskustva iz prakse Suda Europske unije glede primjene članka 265. Ugovora o funkcioniranju Europske unije kojim se propisuje tužba zbog propusta institucija Unije da djeluju, kao i sudska praksa iz Austrije, Češke i Francuske u sporovima zbog propusta donošenja planova za poboljšanje kvalitete zraka. U zadnjem dijelu rada razmatra se mogu li se i na koji način takve tužbe zbog propusta donošenja općeg akta, čija obveza donošenja proizlazi iz prava Europske unije, podnositi pred hrvatskim upravnim sudovima odnosno na koji način bi se u toj situaciji mogle primijeniti postojeće odredbe Zakona o općem upravnom postupku i Zakona o upravnim sporovima.

Ključne riječi: planovi za poboljšanje kvalitete zraka, opći akti, tužba zbog propusta, zaštita od drugih oblika postupanja javnopravnih tijela

\section{UVOD}

Neposredan povod ovom istraživanju dala je presuda Suda Europske unije u predmetu C-237/07 Janecek ${ }^{1}$ u kojem je njemački Savezni upravni sud (Bundesverwaltungsgericht) upitao Sud Europske unije (tadašnji: Sud Europskih zajednica, u daljnjem tekstu: Sud EU-a ili SEU) može li pojedinac zatražiti od nadležnog nacionalnog tijela izradu akcijskog plana za poboljšanje kvalitete zraka u slučaju da postoji rizik da će se granične vrijednosti emisija ili kritične razine prekoračiti. Prema mišljenju Saveznog upravnog suda, temeljem njemačkog prava Janecek nema pravo zahtijevati donošenje akcijskog plana, pa se nametnulo pitanje ima li on to pravo temeljem prava Europske unije (tada: Europske zajednice). Naime, tada važeća Direktiva 96/62/EZ o procjeni i upravljanju kvalitetom vanjskog zraka propisivala je da države članice moraju izraditi akcijske planove koji sadrže mjere

\footnotetext{
1 Presuda u predmetu C-237/07, Janecek, ECLI:EU:C:2008:447.
} 
koje se trebaju poduzeti u kratkom roku, ako postoji rizik da će granične vrijednosti i/ili kritične razine biti prekoračene, kako bi se smanjio taj rizik i ograničilo trajanje takvih pojava.

Sud EU-a u svojoj je presudi utvrdio da je nespojivo s obvezujućim učinkom direktive izuzeti mogućnost da se zainteresirana osoba pozove na obvezu koja je propisana direktivom. To se osobito odnosi na direktive kojima je cilj nadzirati i smanjiti onečišćenje te, time, zaštititi javno zdravlje. Stoga, ako postoji rizik da kritične razine i granične vrijednosti mogu biti prekoračene, osobe koje su izravno zainteresirane moraju biti u mogućnosti zahtijevati od nadležnih nacionalnih vlasti da izrade akcijski plan, čak i ako, prema nacionalnom pravu, te osobe imaju na raspolaganju druga sredstva kojima mogu zahtijevati od nadležnih tijela da poduzmu mjere za borbu protiv onečišćenja. ${ }^{2}$

U hrvatskom upravnom pravu, kao ni u njemačkom upravnom pravu, ne postoji zasebna tužba kojom bi tužitelj mogao tražiti donošenje akcijskog plana. Međutim, kao što to proizlazi iz prakse SEU-a, osobe koje su izravno zainteresirane moraju biti u mogućnosti zahtijevati od nadležnih nacionalnih vlasti izradu akcijskog plana, a ta obveza nadležnih nacionalnih vlasti podvrgnuta je sudskoj kontroli. ${ }^{3}$ Stoga se nameće pitanje mogu li se i na koji način u slučaju takve tužbe zbog nedonošenja akcijskog plana primijeniti postojeće odredbe Zakona o upravnim sporovima (u daljnjem tekstu: ZUS) (v. poglavlje 5. ovog rada). Autorima su pri istraživanju tog pitanja pomogla komparativna iskustva iz prakse Suda EU-a glede primjene članka 265. Ugovora o funkcioniranju Europske unije (u daljnjem tekstu i: UFEU) ${ }^{5}$ kojim se uređuje tužba zbog propusta (v. poglavlje 2. i 3.), kao i sudska praksa iz Austrije, Češke i Francuske (v. poglavlje 4. ovog rada).

Važno je napomenuti da se u radu neće detaljnije razmatrati pravna priroda planova i programa čije se donošenje, osobito u području prava okoliša, propisuje direktivama EU-a, jer je to opsežno pitanje kojemu bi se moglo posvetiti buduće zasebno istraživanje. ${ }^{6}$ Za potrebe ovog rada dovoljno je ispitati zadovoljavaju li akcijski planovi za poboljšanje kvalitete zraka određene kriterije da bi se mogli smatrati općim aktima.

U hrvatskoj pravnoj literaturi o općim aktima pisalo se prvenstveno u kontekstu problema nekadašnje (neadekvatne) kontrole ustavnosti i zakonitosti općih akata,?

2 Ibid., par. 37-42. V. i Ofak, L., „Pravna zaštita kvalitete zraka u europskom i hrvatskom pravu“, u: Barbić, J. (ur.), Pravna zaštita zraka, Zagreb, Hrvatska akademija znanosti i umjetnosti, 2017., str. 96-97.

3 Ibid., par. 47.

${ }^{4}$ NN br. 20/2010, 143/2012, 152/2014, 94/2016 - Odluka Ustavnog suda RH, 29/2017.

5 Pročišćena inačica iz 2016., SL C 202, 7. VI. 2016.

6 Problem pravne prirode planova i programa istaknut je u doktorskoj disertaciji Ofak, L., Pravo na upravnosudsku zaštitu u pitanjima okoliša, Pravni fakultet u Zagrebu, 2012., str. 349-354. Medvedović napominje da analiza sadržaja drugih općih akata koji se donose pod nazivom plan, program ... pokazuje da su neki od njih po pravnoj naravi općenormativni akti (propisi) jer sadržavaju pravne norme kojima se uređuju neka važna pitanja za širi krug objekata - Medvedović, D., „Kontrola ustavnosti i zakonitosti općih akata općina i gradova“, Hrvatska javna uprava, vol. 1, br. 3-4, 2001., str. 506.

7 Medvedović, D. (ibid.); Medvedović, D., „Nadzor izvršne vlasti nad općim aktima jedinica lokalne samouprave de lege lata i de lege ferenda“, Hrvatska javna uprava, vol. 5, br. 1, 2005., str. 81-110. 
kao i povodom donošenja novog ZUS-a koji je uveo ocjenu zakonitosti općih akata pred Visokim upravnim sudom Republike Hrvatske. ${ }^{8}$ Pod pojmom opći akti, za potrebe ovog rada, smatrat će se podzakonski općenormativni akti kojima se na apstraktan i generalan način uređuju određeni društveni odnosi, a koje donose jedinice lokalne i područne (regionalne) samouprave, pravne osobe koja ima javnu ovlast i pravne osobe koja obavlja javnu službu. Kao važno obilježje tako definiranih općih akata smatramo njihovu sposobnost da proizvode pravne učinke, ${ }^{9}$ bilo na način da se na temelju njih donose konkretni pojedinačni akti ili poduzimaju ili propuštaju radnje, ${ }^{10}$ bilo da se njima neposredno zadire u prava, pravne interese ili pravni položaj adresata. Iako donositelji podzakonskih općenormativnih akata mogu biti i tijela državne vlasti (u pravilu tijela izvršne državne vlasti i tijela državne uprave odnosno njihovi čelnici), zbog prostornih ograničenja naše istraživanje ne obuhvaća takve opće akte odnosno „druge propise“ čija je ocjena zakonitosti u nadležnosti Ustavnog suda Republike Hrvatske. ${ }^{11}$

Kao što je već spomenuto, Direktiva Vijeća 96/62/EZ o procjeni i upravljanju kvalitetom vanjskog zraka propisivala je da su u slučaju prekoračenja razina onečišćujućih tvari države članice obvezne provesti akcijske planove za saniranje situacije. ${ }^{12}$ Stoga moramo zaključiti da ako postoji obveza za donošenje i provedbu tih planova, onda u pogledu svoje pravne prirode takvi akcijski planovi nisu puke neobvezujuće smjernice ili preporuke, već se donose s ciljem da proizvedu pravne učinke. U pogledu sadržaja takvih planova, možemo spomenuti da je posljednjih godina mnogo lokalnih zajednica u Njemačkoj usvojilo planove za poboljšanje kvalitete zraka. U njima su, primjerice, uspostavljena područja niskih emisija prometa (Low Emission Zone (LEZ)) u kojima je dozvoljen promet samo vozilima s niskim emisijama. Vlasnici vozila pokušali su takve odredbe osporiti pred sudovima, ali neuspješno. ${ }^{13}$ Osim toga, u veljači 2018. njemački Savezni upravni sud presudio

8 V. primjerice, Omejec, J., Banić, S., „Diferencijacija propisa i općih akata u budućoj praksi Ustavnog suda i Upravnog suda u povodu Zakona o upravnim sporovima (2010.)“, Zbornik Pravnog fakulteta u Splitu, vol. 49, br. 2, 2012., str. 309-324; Banić, S., „,Režim općih akata nakon donošenja Zakona o upravnim sporovima (2010.)“, Zbornik radova Pravnog fakulteta u Splitu, vol. 50, br. 3, 2013., str. 573-588; Staničić, F., Đanić, A., ,Ocjena zakonitosti (i ustavnosti) općih akata u hrvatskom pravu i praksa Visokog upravnog suda Republike Hrvatske“, Hrvatska i komparativna javna uprava, vol. 14, br. 4, 2014., str. 961-986.

9 V. Staničić, F., Đanić, A., op. cit., str. 967-968.

10 V. Medvedović, op. cit. (bilj. 7), str. 84.

11 V. čl. 125. Ustava Republike Hrvatske (NN br. 56/1990, 135/1997, 113/2000, 28/2001, 76/2010 i 5/2014).

12 Godine 2008. usvojena je nova Direktiva 2008/50/EZ Europskog parlamenta i Vijeća od 21. svibnja 2008. o kvaliteti zraka i čišćem zraku za Europu. Nova je Direktiva objedinila izvornu Direktivu 96/62/EZ i većinu direktiva koje su propisivale posebne metodologije za procjenu razine pojedinih vrsta onečišćujućih tvari u atmosferi i detaljne vrijednosti kvalitete zraka zajedno s brojnim pomoćnim instrumentima. U većini slučajeva zadržani su isti standardi. Glavna se razlika odnosila na usvajanje novih standarda u pogledu lebdećih čestica $\mathrm{PM}_{2,5}$ koji nisu bili uključeni u prethodnoj direktivi (v. Ofak, L., op. cit. (bilj. 2), str. 79).

13 V. Doerig, H., ,The German Courts and European Air Quality Plans“, Journal of Environmental Law (2014) 26 (1), str. 143. Autor citira sljedeće presude njemačkih sudova: Bundesverwaltungsgericht (presuda od 11. srpnja 2012.), BVerwG 3 B 78.11, Neue Zeitschrift für Verwaltungsrecht 2012, 1175; Visoki upravni sud Berlin-Brandenburg (presuda od 20. listopada 2011.), OVG 1 B 4.10, Deutsches Autorecht 2012, 157. 
je da čak i zabrana prometa može biti dopuštena ako druge mjere nisu dovoljno učinkovite da osiguraju adekvatnu kvalitetu zraka. ${ }^{14}$

Zaključno, akcijski planovi za poboljšanje kvalitete zrake jesu opći akti, pa će se u radu razmotriti pitanje mogućnosti podnošenja tužbe zbog propusta donošenja jednog takvog općeg akta. Prema odredbi članka 46. stavka 1. Zakona o zaštiti zraka (u daljnjem tekstu: ZZZ) ${ }_{15}^{15}$ predstavničko tijelo jedinice lokalne samouprave, odnosno Grada Zagreba, donosi akcijski plan za poboljšanje kvalitete za svoje administrativno područje, ako u određenoj zoni ili aglomeraciji razine onečišćujućih tvari u zraku prekoračuju bilo koju graničnu vrijednost ili ciljnu vrijednost. Cilj je takvih planova, u što je mogućem kraćem vremenu, osigurati postizanje graničnih ili ciljnih vrijednosti. Akcijski plan mora se donijeti u roku od 18 mjeseci od kraja one godine u kojoj je utvrđeno prekoračenje (čl. 46. st. 5. ZZZ-a). Onečišćivač je dužan provesti i financirati mjere za smanjivanje onečišćenja zraka utvrđenih u akcijskom planu (čl. 46. st. 10. ZZZ-a). Inspektori u provedbi inspekcijskog nadzora temeljem Zakona o zaštiti zraka ovlašteni su i dužni nadziranoj osobi narediti provedbu mjera zaštite zraka iz akcijskog plana koji je izdalo nadležno tijelo u jedinici lokalne samouprave (čl. 131. st. 1. ZZZ-a). Propisana je i prekršajna odgovornost za neprovođenje i nefinanciranje mjera iz akcijskog plana (čl. 145. st. 1. ZZZ-a). Iz svega navedenoga zaključujemo da je po svojoj pravnoj prirodi akcijski plan za poboljšanje kvalitete zraka opći akt. Važno je napomenuti da ne smatramo da su svi akcijski planovi koje donose javnopravna tijela opći akti, već da je u svakom konkretnom slučaju potrebno utvrditi pravnu prirodu nekog akta o kojemu je riječ.

\section{TUŽBA ZBOG PROPUŠTANJA POSTUPANJA PREMA UGOVORU O FUNKCIONIRANJU EU-A}

Prema Ugovoru o funkcioniranju EU-a isti postupak provodi se i za osporavanje pojedinačnih i za osporavanje općenormativnih akata koje donose institucije, tijela, uredi ili agencije EU-a (čl. 263. - 264.). Jednako tako, kontrola zakonitosti propuštanja donošenja pojedinačnih akata i propuštanja donošenja općenormativnih akata uređena je istom odredbom UFEU-a (čl. 265.). ${ }^{16}$ Nadležnost za odlučivanje po tužbi zbog propusta podijeljena je između Suda i Općeg suda ${ }^{17}$ prema istim kriterijima kao i kod tužbi za poništenje. Sud ima isključivu nadležnost za tužbe

14 BVerwG (presuda od 27. veljače 1028.) 7 C 30.17.

15 NN br. 130/2011, 47/2014, 61/2017, 118/2018.

16 O tome v. Šikić, M., Ofak, L., „Pravna zaštita od nerješavanja upravne stvari u pravu Europske zajednice“, Hrvatska pravna revija, god. IX, br. 1, 2009., str. 19-33; Ljubanović, B., Petrašević, T., Poretti, P., Vuletić, I., Župan, M., Procesno-pravni aspekti prava EU, Pravni fakultet Sveučilišta Josipa Jurja Strossmayera u Osijeku, Osijek, 2016., str. 45-46.

17 Sukladno članku 19. stavku 1. Ugovora o Europskoj uniji (pročišćena inačica iz 2016., SL C 202, 7. VI. 2016., u daljnjem tekstu: UEU), Sud Europske unije obuhvaća Sud, Opći sud i specijalizirane sudove. Jedini specijalizirani sud koji je do sada bio osnovan jest Službenički sud Europske unije koji se od 2005. do 2016. bavio predmetima koji su obuhvaćali institucije EU-a te njihove zaposlenike. Službenički sud ukinut je 2016. i njegovu je nadležnost preuzeo Opći sud. 
država članica protiv Europskog parlamenta i/ili Vijeća (osim za akte Vijeća iz područja državnih potpora, ,,dampinga“ i provedbenih ovlasti) i međuinstitucionalne tužbe. Opći je sud u prvom stupnju nadležan za odlučivanje o ostalim tužbama ove vrste, a posebno o tužbama pojedinaca. ${ }^{18}$

Člankom 265. UFEU-a propisuje se institut tužbe zbog propuštanja postupanja (action for failure to act) protiv točno određenih institucija i tijela Europske unije. Clankom je propisano sljedeće:

Ako Europski parlament, Europsko vijeće, Vijeće, Komisija ili Europska središnja banka propuste djelovati i time povrijede Ugovore, države članice i ostale institucije Unije mogu pred Sudom Europske unije pokrenuti postupak radi utvrđivanja povrede. Ovaj se članak pod istim uvjetima primjenjuje na tijela, urede i agencije Unije koje propuste djelovati.

Pokretanje postupka je dopušteno samo ako je dotična institucija, tijelo, ured ili agencija prethodno bila pozvana da djeluje. Ako u roku od dva mjeseca od takvog poziva dotična institucija, tijelo, ured ili agencija ne zauzme stajalište, postupak se može pokrenuti u daljnjem roku od dva mjeseca.

Pod pretpostavkama utvrđenima u prethodnim stavcima svaka fizička ili pravna osoba može podnijeti Sudu pritužbu zato što joj je institucija Unije propustila uputiti bilo koji akt, osim preporuke ili mišljenja.

Analiza predmetnog članka UFEU-a zahtijeva odgovor na nekoliko pitanja: tko mogu biti tužitelji, tko mogu biti tuženici, protiv kakvog se nepostupanja tužba može podnijeti, koji su rokovi za podnošenje tužbe i kakav je tijek postupka.

\subsection{Tužitelji}

Članak 265. UFEU-a dijeli potencijalne tužitelje na dvije kategorije: institucije EU-a i države članice kao jednu, i fizičke i pravne sobe kao drugu. Ove dvije kategorije tužitelja imaju različit opseg mogućnosti podnošenja tužbi protiv propuštanja postupanja.

\subsubsection{Institucije $E U-a$ i države članice}

Člankom 265. stavkom 1. UFEU-a propisano je kako postupak zbog propuštanja postupanja mogu pred Sudom Europske unije pokrenuti države članice i ostale institucije Unije. Što su to točno institucije EU-a određeno je člankom 13. stavkom 1. UEU-a:

Unija ima institucionalni okvir čiji je cilj promicati njezine vrijednosti, zalagati se za njezine ciljeve, služiti njezinim interesima, interesima njezinih građana i interesima država članica te osigurati koherentnost, učinkovitost i kontinuitet njezinih politika i djelovanja.

18 Sud Europske unije, Prikaz, https://curia.europa.eu/jcms/jcms/Jo2_7024/hr/\#competences (pristup: 26. kolovoza 2019.). 
Institucije Unije su: Europski parlament, Europsko vijeće, Vijeće, Europska komisija,

Sud Europske unije, Europska središnja banka i Revizorski sud.

Od navedenih institucija, jedino SEU nema pravo podići tužbu zbog propuštanja postupanja. Naime, SEU o tužbi odlučuje, ali je i odgovoran za pravnu zaštitu, no sam je ne može tražiti. ${ }^{19}$ Iako članak 265. stavak 2. UFEU-a navodi tijelo, ured ili agenciju EU-a kao moguće tuženike, važno je naglasiti kako te pravne osobe nemaju mogućnost podnositi tužbe radi propuštanja postupanja jer nisu izravno navedene u prvom stavku članka $265 .{ }^{20}$

\subsubsection{Fizičke i pravne osobe}

Sukladno članku 265. stavku 3. UFEU-a, svaka fizička ili pravna osoba može podnijeti SEU-u pritužbu zato što joj je institucija Unije (ali i tijelo, agencija ili ured, prema stavku 1. istog članka) propustila uputiti bilo koji akt, osim preporuke ili mišljenja. Dva su važna pitanja koja je ovdje potrebno razlučiti. Prije svega, mogućnost podizanja tužbe zbog propuštanja postupanja za fizičke i pravne osobe vezana je isključivo za akte koji proizvode pravne učinke. Navedeno proizlazi iz činjenice da je mogućnost podizanja tužbe isključena za nedonošenje mišljenja ili preporuka, akata bez izravnog pravnog učinka. Drugo, važno je razlučiti koncept propuštanja "upućivanja akta" fizičkoj ili pravnoj osobi zbog čega se podnosi tužba. Naime, javlja se pitanje je li nužno tu odredbu tumačiti doslovno i tako omogućiti podizanje tužbe jedino ako nije donijet akt koji je trebao biti izričito naslovljen na fizičku ili pravnu osobu koja će onda podnijeti tužbu, ili navedenu odredbu treba tumačiti šire. SEU je kroz svoju praksu uspostavio šire tumačenje navedene odredbe. Tako SEU traži postojanje izravnog interesa, ${ }^{21}$ odnosno da je fizička ili pravna osoba izravno i individualno zainteresirana za akt koji institucija, tijelo, ured ili agencija EU-a nije usvojila i koji je formalno trebao biti adresiran na drugog (na primjer na državu članicu). ${ }^{22}$

\subsection{Tuženici}

Sukladno članku 265. UFEU-a, mogući tuženici postavljeni su široko. Tako tuženici mogu biti Europski parlament, Europsko vijeće, Vijeće, Komisija, Europska

19 V. mišljenje neovisnog odvjetnika Lenza iz predmeta 13/83, Europski parlament protiv Vijeća Europskih zajednica, t. 2.1.2.1. (Opinion of Mr Advocate General Lenz delivered on 7 February 1985., European Parliament v Council of the European Communities, Case 13/83, ECLI:EU:C:1985:53).

20 Tako i Lenaerts, K., Maselis, I., Gutman, K., EU Procedural Law, Oxford, Oxford University Press, 2014, str. 428.

21 V., npr., par. 16. u presudi u predmetu 246/81, Lord Bethel protiv Komisije, ECLI:EU:C:1982:224, ili par. 41. presude Prvostupanjskog suda u predmetu T-32/93 Landbroke Racing protiv Komisije, ECLI:EU:T:1994:261; Turk, A. H., Judicial Review in EU Law, Cheltenham, Edward Elgar, 2009., str. 194.

22 Lenaerts, K., Maselis, I., Gutman, K., op. cit., str. 430., v. i Eliantonio, M., „Judicial Review in an Integrated Administration: the Case of 'Composite Procedures'", Review of European Administrative Law, br. 65, 2014., str. 91. 
središnja banka, tijela, uredi i agencije EU-a ako su propustili postupiti. Kako je već spomenuto u prethodnom poglavlju, člankom 13. UFEU-a određuju se institucije EU-a. Od tamo navedenih institucija, jedino SEU i Revizorski sud ne mogu biti tuženi za propuštanje postupanja. Također, tužba se ne može podnijeti protiv EU-a u cjelini, ali ni protiv države članice niti Europskog ombudsmana, ${ }^{23}$ niti naravno Europskog suda za ljudska prava koji uopće nije institucija Europske unije. ${ }^{24}$

\subsection{Predmet tužbe}

Nakon utvrđivanja tužitelja i tuženika, nužno je odrediti protiv kakvog se propuštanja postupanja tužba uopće može podnijeti. Tako se u teoriji ističe nekoliko ključnih elemenata koji moraju biti ispunjeni: mora se dogoditi propust postupanja tuženika, mora postojati dužnost postupanja tuženika, tužitelj mora nedvojbeno odrediti postupanje koje nije, a trebalo je biti poduzeto, i akt koji nije usvojen mora biti sposoban imati pravni učinak.

\subsubsection{Propust postupanja tuženika}

Već smo definirali moguće tuženike kao institucije EU-a, tijela, urede ili agencije. O propustu postupanja tuženika govorimo kada tuženik nije donio odluku, akt ili određenu mjeru, a tužba može biti podnijeta jedino ako je tuženik prvo bio pozvan na postupanje, te ako u roku od dva mjeseca od poziva na postupanje nije zauzeo svoje stajalište prema traženom postupanju. ${ }^{25}$ Također, važno je napomenuti kako će razlog za vođenje postupka pred SEU-om nestati ako tuženik nakon što je počeo postupak usvoji traženi akt ili mjeru. Taj stav potvrđuje i praksa SEU-a koja se odnosila na odgovarajuće odredbe tada važećih Osnivačkih ugovora vezane za tužbu zbog propusta (pojedine dijelove istaknuli autori):

Također treba napomenuti da se, prema ustaljenoj sudskoj praksi, pravni lijek predviđen u članku 232. Ugovora o EZ-u, koji služi različitim svrhama od pravnog lijeka predviđenog u članku 226. Ugovora o EZ-u (...), temelji na pretpostavci da nezakonita nepostupanja od strane dotične institucije omogućuju da se predmet pokrene pred Sudom kako bi se utvrdilo da je propuštanje postupanja suprotno Ugovoru, ukoliko dotična institucija ipak nije ispravila propust. Učinak je takvog utvrđenja, prema članku 233. Ugovora o EZ-u, da tužena institucija mora poduzeti potrebne mjere kako bi postupila sukladno presudi Suda, ne dovodeći u pitanje bilo kakvu tužbu zbog izvanugovorne odgovornosti koja se može inicirati povodom navedenog utvrđenja. U okolnostima u kojima je akt, čije odsustvo je predmet postupka, usvojen nakon podnošenja tužbe, ali prije donošenja presude, utvrdenje Suda da je prvobitno nepostupanje nezakonito više ne može dovesti do posljedica propisanih člankom 233. Ugovora o EZ-u. Slijedi da je u takvom slučaju, kao i u slučajevima kada je tužena institucija odgovorila u roku

23 Turk, A. H., op. cit., str. 173.

24 Lenaerts, K., Maselis, I., Gutman, K., op. cit., str. 429.

25 Ibid., str. 421. 
od dva mjeseca nakon što je pozvana da djeluje, predmet tužbe prestao postojati, tako da više nema potrebe za odlučivanjem Suda (...). Činjenica da tužitelj nije zadovoljan sa stajalištem koji je usvojila institucija nije relevantna u tom pogledu jer se članak 232. Ugovora o EZ-u odnosi na propust postupanja u smislu propusta donošenja odluke ili zauzimanja stajališta, a ne na usvajanje mjere drugačije od one koju su zainteresirane osobe htjele ili smatrale potrebnom (...). ${ }^{26}$

Važno je napomenuti kako, sukladno članku 265. UFEU-a, ne postoji pravo na pokretanje tužbe protiv negativnog akta, odnosno akta kojim se odbija donošenje akta za koji potencijalni tužitelj misli da postoji obveza donošenja. ${ }^{27}$ Takav akt jedino se može pobijati sukladno članku 263. UFEU-a.

\subsubsection{Pravna obveza donošenja akta}

\section{Člankom 265. stavkom 1. UFEU-a propisano je sljedeće:}

Ako Europski parlament, Europsko vijeće, Vijeće, Komisija ili Europska središnja banka propuste djelovati i time povrijede Ugovore, države članice i ostale institucije Unije mogu pred Sudom Europske unije pokrenuti postupak radi utvrđivanja povrede. Ovaj se članak pod istim uvjetima primjenjuje na tijela, urede i agencije Unije koje propuste djelovati.

Navedenu odredbu ne smije se tumačiti na način da će se smatrati kako postoji obveza donošenja akta jedino ako je obveza tuženiku nametnuta Ugovorima. Obveza donošenja akta može postojati u bilo kojem aktu EU-a koji je obvezujući za tuženika. ${ }^{28}$

Također, važno je razlikovati situacije u kojima tuženik ima mogućnost diskrecijskog odlučivanja od onih u kojima ima obvezu postupanja. Ako postoji mogućnost diskrecijskog odlučivanja tuženika, tužba zbog propuštanja postupanja ne može se podnijeti. To potvrđuje i praksa SEU-a (pojedine dijelove istaknuli autori):

... svrha zahtjeva je da se utvrdi da je Komisija povrijedila Ugovor propustom da donese odluku time što nije započela postupak protiv Francuske Republike radi utvrđivanja povrede obveza. Međutim, iz članka 169. Ugovora jasno proizlazi da Komisija nije dužna započeti postupak predviđen u toj odredbi, već u tom pogledu ima diskrecijsko pravo koje isključuje pravo pojedinaca da zahtijevaju od te institucije da usvoji određeni stav. Samo ako smatra da dotična država članica nije ispunila neku od svojih obveza, Komisija daje obrazloženo mišljenje. Nadalje, u slučaju da se država ne pridržava mišljenja u predviđenom roku, institucija u svakom slučaju ima pravo, ali ne i dužnost, podnijeti zahtjev Sudu da utvrdi da se dogodila navodna povreda obveza. Također se mora primijetiti da, tražeći od Komisije da pokrene postupak na temelju članka 169., podnositelj zahtjeva zapravo traži donošenje akata koji ga se ne

26 Presuda Općeg suda u predmetu T-423/07, Ryanair protiv Komisije, ECLI:EU:T:2011:226, par. 26.

27 Daukšienè, I., Budnikas, A., „Has the action for failure to act in the European union lost its purpose?"“, Baltic Journal of Law and Politics, v. 7, n. 2, 2014., str. 211.

28 Lenaerts, K., Maselis, I., Gutman, K., op. cit., str. 423. 
tiču izravno i osobno u smislu drugog stavka članka 173. i koja ne bi mogao pobijati tužbom za poništenje. Slijedom toga, podnositelj zahtjeva nema pravo na prigovor da Komisija nije pokrenula postupak protiv Francuske Republike sukladno članku 169. Ugovora. $^{29}$

\subsubsection{Određivanje konkretnog propuštanja postupanja}

Tužitelj mora dovoljno jasno odrediti kakav je akt tuženik propustio donijeti. Navedeno pravilo proizlazi iz prakse SEU-a (pojedine dijelove istaknuli autori):

Sukladno članku 175. Ugovora o EEZ-u, fizička osoba može podnijeti prigovor Sudu da mu je institucija Zajednice propustila uputiti akt, osim preporuke ili mišljenja. $\boldsymbol{U}$ predmetnim postupcima podnositelji zahtjeva nisu naveli koji im je akt, u smislu tog članka, Komisija propustila uputiti. ${ }^{30}$

Također, tužitelj mora dovoljno precizno odrediti sadržaj takvog akta kako bi SEU mogao donijeti presudu kojom bi tužitelja obvezao na njegovo donošenje:

U takvim okolnostima, pitanje koje je postavilo Vijeće je, u biti, je li u ovom predmetu Europski parlament, opisujući u svom prvom zahtjevu mjere koje je Vijeće propustilo poduzeti, učinio to s tolikim stupnjem preciznosti koji bi omogućio Vijeću da se, sukladno članku 176., pridržava presude Suda kojom se taj zahtjev dopušta. Takav stupanj preciznosti posebno je potreban s obzirom na činjenicu da u sustavu pravnih lijekova predviđenih Ugovorom postoji bliska veza između prava na tužbu iz članka 173. koje dopušta da se nezakonite mjere Vijeća i Komisije ponište, a to se temelji na članku 175., što može dovesti do zaključka da propust Vijeća ili Komisije da usvoji određene mjere nije u skladu s Ugovorom. S obzirom na taj odnos, mora se zaključiti da u oba slučaja mjere koje su predmet tužbe moraju biti dovoljno definirane kako bi Sud mogao utvrditi je li njihovo usvajanje ili njihovo nepoduzimanje zakonito. ${ }^{31}$

\subsubsection{Pravni učinak akta čije se donošenje traži}

Utvrđujući pravni učinak akta koje je nadležno tijelo EU-a propustilo donijeti, nužno je razlikovati je li postupak zbog propuštanja postupanja pokrenula država članica ili institucija EU-a, ili fizička ili pravna osoba.

Ako postupak pokreće država članica ili institucija EU-a, važno je napomenuti da traženi akt ne mora biti obvezujući kako bi imao pravni učinak, ${ }^{32}$ budući da postoje situacije u kojim je donošenje neobvezujućeg akta institucije EU-a preduvjet kako bi druga institucija donijela obvezujući akt. Stoga, propuštanje usvajanja

\footnotetext{
29 Presuda u predmetu 247/87, Star Fruit protiv Komisije, ECLI:EU:C:1989:58, par. 10-14.

30 Rješenje Suda u spojenim predmetima 114-117/79, Fournier protiv Komisije, ECLI:EU:C:1980:124.

31 Presuda u predmetu 13/83, Europski parlament protiv Vijeća, ECLI:EU:C:1985:220, par. 35-36.

32 Lenaerts, K., Maselis, I., Gutman, K., op. cit., str. 425.
} 
neobvezujućeg akta onemogućuje donošenje obvezujućeg, te se zato i protiv nedonošenja takvog akta mora dopustiti pravni lijek. ${ }^{33}$

S druge strane, ako postupak zbog propuštanja postupanja pokreće fizička ili pravna osoba, postupak se može pokrenuti jedino ako institucija, tijelo, ured ili agencija EU-a nije usvojila obvezujući akt, što proizlazi iz tumačenja trećeg stavka članka 265. UFEU-a, kojim se dopušta pokretanje postupka protiv akata koji nisu preporuke ili mišljenja. Kako preporuke i mišljenja nisu obvezujući akti, može se zaključiti da fizičke i pravne osobe postupak mogu pokretati jedino zbog nedonošenja obvezujućih akata.

Praksa SEU-a uspostavlja još jedno važno pravilo. Naime, ako je tijelu EU-a dana diskrecijska ovlast kod odlučivanja hoće li donijeti određeni akt ili ne, zbog nedonošenja takvog akta ne može se pokrenuti postupak zbog propuštanja postupanja:

Uzimajući u obzir cilj Uredbe o ENPI-u, a to je potpora vanjskim politikama Europske unije, pitanje provedbe članka 28. te Uredbe, u okviru kojega Komisija upućuje prijedlog Vijeću, pitanje je diskrecijskog prava Komisije. U skladu sa sudskom praksom, izvršavanje takve diskrecije isključuje pravo pojedinca da zahtijeva od Komisije da zauzme stajalište u vezi s tim (...). Stoga se mora zaključiti da, uzimajući u obzir diskrecijsko pravo Komisije u pogledu podnošenja prijedloga Vijeću na temelju članka 28. Uredbe o ENPI-ju, nije moguće pozivati se na njezin propust da uputi takav prijedlog Vijeću u okviru tužbe koja se temelji na trećem stavku članka 232. Ugovora $o E Z-u^{34}$

\subsection{Postupak zbog propuštanja postupanja}

Člankom 265. stavkom 2. UFEU-a propisano je kako je pokretanje postupka dopušteno samo ako je institucija, tijelo, ured ili agencija prethodno bila pozvana na postupanje. Ako u roku od dva mjeseca od takvog poziva dotična institucija, tijelo, ured ili agencija ne zauzme stajalište, postupak se može pokrenuti u daljnjem roku od dva mjeseca.

Dakle, glavni preduvjet kako bi se uopće mogao pokrenuti postupak zbog propuštanja postupanja pred SEU-om jest prethodni poziv tijelu na postupanje, a taj postupak naziva se preliminarnim postupkom.

\subsubsection{Preliminarni postupak}

Prethodni poziv započinje upućivanjem nekog oblika komunikacije odnosno obavijesti tijelu koje nije donijelo traženi akt. Ta komunikacija imat će oblik

33 Npr. pokretanje postupka zbog propuštanja postupanja protiv Vijeća koje nije donijelo nacrt proračuna, neobvezujući akt bez kojeg Parlament ne može donijeti proračun (presuda u predmetu 377/87, Parlament protiv Vijeća, ECLI:EU:C:1988:387).

34 Rješenje Općeg suda u predmetu T-292/09, Mugraby protiv Vijećai Komisije, ECLI:EU:T:2011:418, par. 38-39. 
službene obavijesti, čiji je prvenstveni pravni učinak činjenica da od upućivanja navedene obavijesti kreće dvomjesečni rok u kojem se institucija, agencija, tijelo ili ured moraju izjasniti. Također, važno je naglasiti kako ta komunikacija nema točno propisanu formu, ali praksa SEU-a određuje da mora ispuniti sljedeće uvjete: a) mora pozvati instituciju, tijelo, ured ili agenciju na postupanje, b) mora jasno naznačiti da je njen pravni temelj članak 265. UFEU-a, c) mora jasno naznačiti koje mjere očekuje da se usvoje, te d) mora jasno naznačiti koje tijelo, pravna ili fizička osoba podnosi samu komunikaciju. ${ }^{35}$

Sljedeće pitanje koje se postavlja jest, u kojem se roku od mogućeg propuštanja poduzimanja od institucije, tijela, ureda ili agencije može tražiti postupanje. Navedeno će biti jednostavno odrediti u situacijama u kojima je propisan rok u kojem institucija, tijelo, ured ili agencija moraju postupiti, ali u većini slučajeva to neće biti tako. ${ }^{36}$

SEU neodređeno navodi kako se to mora učiniti u razumnom roku, što će se onda određivati od slučaja do slučaja. ${ }^{37}$ Dobar primjer te prakse jest i sljedeća presuda SEU-a:

Međutim, iz zajedničkog cilja članaka 33. i 35. proizlazi da se uvjeti pravne sigurnosti $i$ kontinuiteta postupanja Zajednice na kojima se temelje vremenski rokovi predviđeni za pokretanje postupka na temelju članka 33. također moraju uzeti u obzir-uzimajući u obzir posebne poteškoće koje bi šutnja nadležnih tijela mogla prouzročiti za zainteresirane strane - u ostvarivanju prava iz članka 35. Ti zahtjevi ne smiju dovesti do takvih kontradiktornih posljedica kao što je dužnost postupanja u kratkom roku u prvom slučaju i nepostojanje bilo kakvog vremenskog ograničenja u drugom. Ovo stajalište nalazi podršku u sustavu rokova u članku 35. koji Komisiji omogućuje dva mjeseca da zauzme svoje stajalište, a zainteresiranoj strani mjesec dana za pokretanje postupka pred Sudom. Stoga je u sustavu clanaka 33. i 35. implicitno da ostvarivanje prava na pokretanje postupka pred Komisijom ne može biti neograničeno. Ako su stoga zainteresirane strane obvezne poštivati razumni rok kada Komisija propušta postupiti, to je a fortiori nakon što je jasno da je Komisija odlučila ne poduzimati nikakve mjere. ... S obzirom na ove okolnosti, razdoblje od osamnaest mjeseci između priopćenja od 9. prosinca 1968. i zahtjeva upućenog Komisiji 24. lipnja 1970. kako bi se pokrenuo postupak predviđen člankom 35. ne može se smatrati razumnim (...). ${ }^{38}$

Nakon što je institucija, agencija, tijelo ili ured pozvan da djeluje, počinje teći rok od dva mjeseca u kojem mora zauzeti stajalište. Ovdje je važno naglasiti nekoliko ključnih odrednica. Naime, kroz praksu SEU-a ustanovljeno je kako je za zauzimanje stajališta važniji sadržaj od forme. Naime, ključno je da traženo tijelo navede svoje stajalište o traženom aktu i njegovu donošenju, a ne oblik u kojem će to učiniti. Tako tijelo stajalište može zauzeti pismom, teleksom, ali i usvajanjem

\footnotetext{
35 Lenaerts, K., Maselis, I., Gutman, K., op. cit., str. 434.

36 Daukšienè, I., Budnikas, A., op. cit., str. 213.

37 Lenaerts, K., Maselis, I., Gutman, K., op. cit., str. 433., tako i Turk, A. H., op. cit., str. 185.

38 Presuda u predmetu 59/70, Nizozemska protiv Komisije, ECLI:EU:C:1971:77, par. 15-22.
} 
mjere suprotne od one koja je tražena. ${ }^{39} \mathrm{U}$ svakom slučaju, zauzimanje stajališta mora biti u pisanom obliku. ${ }^{40}$ Ipak, izjava institucije, tijela, ureda ili agencije kojom navodi kako je krenula razmatrati pitanje zbog kojeg se traži zauzimanje stajališta ne može se smatrati zauzimanjem stajališta:

Podnositelj zahtjeva je ispravno istaknuo da to pismo ni na koji način ne definira stajalište Komisije u odnosu na predmetne prigovore jer Komisija jednostavno navodi da je, nakon što je ispitala prigovore i nakon završetka vanjske studije, zatražila od španjolskih vlasti dodatne informacije. Pismo institucije koju se poziva da postupi u skladu s člankom 175. Ugovora u kojem se navodi da se postavljena pitanja razmatraju, zapravo ne znači zauzimanje stajališta koje bi ga oslobodilo dužnosti postupanja (.....41

Nakon što institucija, tijelo, ured ili agencija zauzmu stajalište, podnošenje tužbe SEU-u postaje nemoguće. Također, ako se zauzme stajalište koje nije u skladu sa željama podnositelja zahtjeva, ponovno nije moguće podnijeti tužbu. To je prije svega zato što se člankom 265. UFEU-a štiti od propuštanja postupanja, a ne od mjera koje se razlikuju od traženih: ${ }^{42}$

U ovome predmetu, Sud primjećuje da je Komisija 23. lipnja 1995. odgovorila na dopis podnositelja zahtjeva od 20. travnja 1995. godine, ističući, u biti, da njezin zahtjev spada u djelokrug država članica. Uzevši u obzir to pismo, koje jasno navodi Komisijin stav u odnosu na zahtjev podnositelja zahtjeva, ne može se reći da ta institucija nije postupila. Činjenica da stajalište Komisije nije zadovoljilo podnositelja zahtjeva u tom pogledu nije bitno. Članak 175. Ugovora odnosi se na propust da se postupi u smislu propusta donošenja odluke ili zauzimanja stajališta, a ne na usvajanje mjere drugačije od one koju su zainteresirane osobe htjele ili smatrale potrebnom (.....43

\subsubsection{Postupak pred SEU-om}

Ako je institucija, tijelo, ured ili agencija pozvana na postupanje sukladno prethodnom poglavlju, i ne djeluje ili zauzme stav u roku od dva mjeseca od poziva, tužitelj može pokrenuti postupak pred SEU-om (Općim sudom). Taj postupak može se pokrenuti u dodatnom roku od dva mjeseca od isteka prethodnog roka od dva mjeseca za postupanje tražene institucije. Važno je napomenuti da ako institucija, agencija, ured ili tijelo zauzmu stajalište nakon što je pokrenut postupak, ali prije nego li je donesena presuda, tužba postaje bespredmetna, ali moguće je tražiti naknadu troškova postupka. ${ }^{44}$

Ako SEU (Opći sud) presudi u korist tužitelja i utvrdi da je institucija, tijelo, ured ili agencija povrijedila Ugovore propustom postupanja, predmetna institucija, tijelo,

39 Lenaerts, K., Maselis, I., Gutman, K., op. cit., str. 434.

40 Daukšienė, I., Budnikas, A., op. cit., str. 215.

41 Presuda Prvostupanjskog suda u predmetu T-95/96, Gestevision Telecinco protiv Komisije, ECLI:EU:T:1998:206, par. 88.

42 Lenaerts, K., Maselis, I., Gutman, K., op. cit., str. 435.

43 Rješenje Prvostupanjskog suda u predmetu T-226/95, Kuchlenz-Winter protiv Komisije, ECLI:EU:T:1996:173, par. 31.

44 Lenaerts, K., Maselis, I., Gutman, K., op. cit., str. 438. 
ured ili agencija dužna je, sukladno članku 266. UFEU-a, postupiti prema presudi. ${ }^{45}$ SEU nema ovlast donijeti traženi akt umjesto institucije, tijela, ureda ili agencije koja je traženi akt bila dužna donijeti. ${ }^{46}$

\section{PRAKSA SUDA EUROPSKE UNIJE U SPOROVIMA ZBOG PROPUSTA DONOŠENJA OPĆEG AKTA}

Praksu Suda Europske unije istražili smo na način da smo u pretraživaču sudske prakse na web-stranici Suda odabrali opciju da se pretraživanje odnosi na tužbe zbog propusta od 1. srpnja 2013. kada je Hrvatska postala članicom EU-a do 15. kolovoza 2019. (dan izvršenog pretraživanja). Rezultat pretraživanja pokazao je da su takvi predmeti rijetki, a većina ih se uopće ne odnosi na propuštanje donošenja općeg akta. Najčešće je riječ o postupcima u kojima fizičke ili pravne osobe podnose tužbu protiv Komisije zbog njezina propusta da pokrene postupak protiv neke države članice radi utvrđivanja povrede. SEU takve tužbe odbacuje zbog nedopuštenosti. ${ }^{47}$

Presuda u predmetu T-521/14, Švedska protiv Komisije, ${ }^{48}$ jedini je primjer usvajanja tužbe zbog propusta Europske komisije da donese opći akt u istraženom razdoblju. U toj je presudi SEU (Opći sud) utvrdio da Europska komisija nije ispunila obveze iz Uredbe br. 528/2012 o stavljanju na raspolaganje na tržištu i uporabi biocidnih proizvoda, time što nije donijela delegirane akte u kojima bi bili navedeni znanstveni kriteriji za određivanje svojstava endokrinih poremećaja. Biocidni proizvodi (dezinficijensi za kućanstvo, insekticidi i ostale kemikalije) potrebni su za kontrolu organizama koji su štetni za zdravlje ljudi ili životinja te za kontrolu organizama koji štete prirodnim ili proizvedenim materijalima. Biocidni proizvodi, međutim, zbog svojih svojstava i povezanih načina uporabe mogu predstavljati rizik za ljude, životinje i okoliš. U svrhu poboljšanja slobodnog kretanja biocidnih proizvoda u Uniji uz istodobno osiguranje visokog stupnja zaštite zdravlja ljudi, zdravlja životinja te okoliša usvojena je Uredba br. 528/2012 o stavljanju na raspolaganje na tržištu i uporabi biocidnih proizvoda. U Uredbi se propisuju aktivne tvari za koje se ne može dobiti odobrenje. To uključuje aktivne tvari za koje se, na temelju određenih kriterija koji se trebaju usvojiti, smatra da imaju svojstva endokrine disrupcije ili koje su određene kao tvari koje imaju svojstva endokrine disrupcije. Endokrino disruptivne kemijske tvari jesu tvari koje mijenjaju funkcije hormonskog sustava i na taj način izazivaju štetne učinke. Uredba propisuje da je Komisija bila dužna najkasnije do 13. prosinca 2013. donijeti delegirane akte

45 Ibid., str. 439.

46 Turk, A. H., op. cit., str. 202.

47 V. supra u poglavlju 2.3.2. za pojašnjenje prakse.

48 Presuda Općeg suda u predmetu T-521/14, Kraljevina Švedska protiv Europske komisije, ECLI:EU:T:2015:976. 
u kojima će navesti znanstvene kriterije za određivanje svojstava endokrinih poremećaja. ${ }^{49}$ Svoju dužnost Komisija nije ispunila.

Švedska je 4. srpnja 2014. podnijela tužbu pred SEU-om (Općim sudom) protiv Komisije zbog propusta da u propisanom roku donese delegirane akte koje je bila dužna donijeti. Opći sud je u svojoj presudi najprije utvrdio da je formulacija članka 5. stavka 3. podstavka Uredbe br. 528/2012 jasna i nedvosmislena. Jasno je da ta odredba izričito propisuje da je Komisija imala jasnu, preciznu i bezuvjetnu obvezu donošenja delegiranih akata u vezi sa specifikacijom znanstvenih kriterija za određivanje svojstava poremećaja endokrinog poremećaja do 13. prosinca 2013. Nesporno je da Komisija nije usvojila takve akte, a nijedan argument koji je Komisija navela ne dovodi u pitanje postojanje obveze usvajanja tih akata niti opravdava nedonošenje tih akata. ${ }^{50}$ Opći sud također je naglasio da, nakon usvajanja te uredbe, zakonodavac nije izmijenio ni ukinuo rok za donošenje delegiranih akata utvrđen u prvom podstavku članka 5. stavka 3. Uredbe br. 528/2012. Niti je Komisija predložila zakonodavcu da izmijeni tu uredbu u svrhu produljenja tog roka. Prihvaćanje stajališta da se rok izričito utvrđen tom odredbom ne bi smatrao obvezujućim, značilo bi dovoditi u pitanje delegiranje tj. prenošenje ovlasti donošenja nezakonodavnih akata opće primjene koje je zakonodavac odobrio Komisiji. $^{51}$

Zanimljiva je argumentacija kojom je Komisija pokušala opravdati svoj propust. Tvrdila je da su znanstveni kriteriji koje je predložila u ljeto 2013. kritizirani da nisu znanstveno valjani te da bi njihova primjena utjecala na unutarnje tržište. S tim je u vezi Opći sud utvrdio kako protivljenje interesnih skupina da se donesu regulatorne mjere ne opravdava propust Komisije da ispuni svoju dužnost koju joj je dao zakonodavac u Uredbi. ${ }^{52}$ Komisija je također navela da nema nikakvih praktičnih posljedica toga što nisu usvojeni delegirani akti. Međutim, Opći sud je napomenuo da to nije relevantno. Naime, ocjena osnovanosti tužbe zbog propusta ovisi isključivo o pitanju je li institucija koja ima obvezu postupanja postupila ili propustila postupiti. Dakle, čak i pod pretpostavkom da propuštanje nema praktične posljedice, to ne bi utjecalo na ocjenu osnovanosti tužbe. ${ }^{53}$ Konačno, Opći sud odbio je i argument Komisije da važeći privremeni kriteriji jamče dovoljno visoku razinu zaštite. Budući da je zakonodavac izričito predvidio da se privremeni kriteriji primjenjuju samo do donošenja mjera navedenih u prvom podstavku članka 5. stavka 3. Uredbe br. 528/2012, ti se privremeni kriteriji ne mogu smatrati pružanjem dovoljno visoke razine zaštite za ispunjenje ciljeva te odredbe. ${ }^{54} \mathrm{Iz}$ svih navedenih razloga, Opći je

49 Prvi podstavak članka 5. stavka 3. Uredbe br. 528/2012 glasi: „3. Najkasnije 13. prosinca 2013. Komisija će donijeti delegirane akte u skladu s člankom 83. u kojima će navesti znanstvene kriterije za određivanje svojstava endokrinih poremećaja." $53-58$

50 Presuda Općeg suda u predmetu T-521/14, Kraljevina Švedska protiv Europske komisije, par.

\footnotetext{
Ibid., par. 62.

52 Ibid., par. 69-71.

53 Ibid., par. 75.

54 Ibid., par. 77.
} 
sud presudio da Europska komisija nije ispunila obveze na temelju članka 5. stavka 3. prvog podstavka Uredbe br. 528/2012 o stavljanju na raspolaganje na tržištu i uporabi biocidnih proizvoda, time što nije donijela delegirane akte u kojima bi bili navedeni znanstveni kriteriji za određivanje svojstava endokrinih poremećaja.

Što se tiče ostalih tužbi koje su bile u postupku pred Sudom Europske unije u istraženom razdoblju koje podnose fizičke ili pravne osobe, sudska praksa - premda rijetka - pokazuje da se tužbe zbog propusta institucija EU-a da donesu neki opći akt odbacuju kao nedopuštene zbog nedostatka pravnog interesa tužitelja za podnošenje takvih tužbi. U nastavku ćemo analizirati dva takva predmeta.

U prvom predmetu koji ćemo razmotriti - T-578/14, VSM Geneesmiddelen protiv Komisije - tužitelj je od SEU-a (Općeg suda) zahtijevao da utvrdi da je Komisija nezakonito propustila provesti ocjenu zdravstvenih tvrdnji u pogledu botaničkih tvari od strane Europske agencije za sigurnost hrane u skladu s postupkom predviđenim člankom 13. stavkom 3. Uredbe (EZ) 1924/2006 od 1. kolovoza 2014. U prilog tužbi, tužitelj je naveo da je, u skladu s člankom 13. stavkom 3. Uredbe o zdravstvenim tvrdnjama, Komisija bila dužna donijeti popis dozvoljenih tvrdnji u pogledu tvari korištenih u hrani najkasnije do 31. siječnja 2010. U okviru donošenja takvog popisa Europska agencija za sigurnost hrane (EFSA) bila je zadužena za ocjenu zdravstvenih tvrdnji koje su dostavile države članice. Međutim, u rujnu 2010., Komisija je objavila da će ukinuti i preispitati postupak ocjene tvrdnji u pogledu botaničkih tvari, te je EFSA prestala ispitivati te tvrdnje. Podsjećamo da se tužba zbog propusta može podnijeti ne samo zbog propuštanja donošenja akta kojim se stvaraju obvezujući pravni učinci koji mogu utjecati na interese tužitelja, mijenjajući na karakterističan način njegovu pravnu situaciju, nego i zbog propuštanja donošenja pripremnog akta, ako je on nužan preduvjet za provedbu postupka u okviru kojeg će se donijeti akt koji proizvodi obvezujuće pravne učinke. ${ }^{55}$ Komisija je prekinula samo postupak ocjene u pogledu botaničkih tvari, ali ne i postupak u pogledu drugih tvari, kao što su kemijske tvari. Iako je u konkretnom slučaju tužba odbačena kao nedopuštena iz razloga što je bila podnesena preuranjeno (jer tužitelj nije sačekao istek dvomjesečnog roka od svog poziva Komisije da djeluje), Opći je sud radi cjelovitosti razmotrio i argumente Komisije u kojima je tvrdila da tužitelj nema interes za pokretanje postupka. U pogledu pravnog interesa Opći sud je istaknuo:

Ustaljena je sudska praksa da je interes za pokretanje postupka ključni i osnovni preduvjet bilo kojeg pravnog postupka (...). Stoga svaki tužitelj mora dokazati, u pogledu cilja svoje tužbe, da ima interes za pokretanje postupka, koji mora postojati u stadiju podnošenja tužbe, u protivnom će tužba biti nedopuštena (...). Interes za pokretanje postupka pretpostavlja da tužba može, kao rezultat njezinog ishoda, donijeti korist za osobu koja je podnijela tužbu (...). Konačno, tužitelj mora dokazati da ima interes za pokretanje postupka, koji mora biti postojeći i stvaran. Ako se interes na koji

55 V. poglavlje 2.3.4. ovog rada. 
se tužitelj poziva odnosi na buduću pravnu situaciju, mora dokazati da je negativan utjecaj na tu situaciju već izvjestan (....). ${ }^{56}$

U konkretnom je slučaju Opći sud utvrdio da tužitelj nije dokazao da bi nastavak ocjene zdravstvenih tvrdnji koje se odnose na botaničke tvari i prihvaćanje konačnog popisa dozvoljenih zdravstvenih tvrdnji moglo donijeti korist za njega, kako to zahtijeva sudska praksa. Naime, kao što je istaknula Komisija, trenutna regulatorna situacija, prema kojoj se zdravstvene tvrdnje za koje je postupak prekinut i dalje mogu navoditi, može za tužitelja biti povoljnija od situacije u kojoj se njegove zdravstvene tvrdnje odbijaju. Subjekti na koje utječe prekid postupka mogu nastaviti navoditi tvrdnje koje su suspendirane pod uvjetom da ispunjavaju prijelazne mjere propisane u članku 28. stavcima 5. i 6. Uredbe br. 1924/2006. U tom je pogledu Opći sud utvrdio da prijelazno uređenje ispunjava zahtjeve načela pravne sigurnosti prema kojemu pravna pravila moraju biti jasna i precizna, a njihove posljedice predvidljive. ${ }^{57}$ Imajući u vidu gore navedeno, Opći sud je zaključio da se tužba morala odbaciti kao nedopuštena i iz razloga što podnositelj zahtjeva nije dokazao interes za pokretanje postupka. ${ }^{58}$ Naposljetku je i žalba protiv rješenja o odbacivanju tužbe bila odbijena. ${ }^{59}$

U drugom predmetu - T-773/16, Salehi protiv Europske komisije - tužitelj je podnio tužbu kojom je zahtijevao utvrđenje da je Komisija nezakonito propustila donijeti provedbeni akt u smislu članka 1. stavka 4. Uredbe Vijeća (EZ) br. 539/2001 o popisu trećih zemalja čiji državljani moraju imati vizu pri prelasku vanjskih granica i zemalja čiji su državljani izuzeti od tog zahtjeva. Tužitelj je u osnovi tražio od Komisije da usvoji delegirani akt, kako bi privremeno suspendirala izuzeće od zahtjeva za vizu za neke državljane Sjedinjenih Američkih Država koji žele pristupiti teritorijima država članica.

Opći sud najprije je podsjetio da prema ustaljenoj sudskoj praksi uvjet da fizička ili pravna osoba mora biti izravno povezana s odlukom koja se osporava, kako je predviđeno člankom 263., stavak 4. UFEU-a, zahtijeva ispunjavanje dva kumulativna kriterija, naime da sporna mjera s jedne strane ima izravan učinak na pravni položaj pojedinca, a s druge strane da ne ostavlja diskrecijsko pravo njezinim adresatima koji su odgovorni za njezinu provedbu, koja je čisto automatska i koja proizlazi samo iz pravila Unije, bez primjene drugih posrednih pravila. ${ }^{60}$ Opći sud je utvrdio da jedine osobe na koje bi se izravno odnosilo eventualno donošenje akta bili bi američki državljani koji žele posjetiti države članice, a koji više ne bi mogli iskoristiti izuzeće od zahtjeva za vizu. ${ }^{61}$ Slijedom je toga Opći sud zaključio da se

56 Rješenje Općeg suda u predmetu T-578/14, VSM Geneesmiddelen protiv Komisije, ECLI:EU:T:2015:715, par. 42-45.

57 Ibid., par. 63-64.

58 Ibid., par. 68.

59 Rješenje Suda u predmetu C-637/15 P, VSM Geneesmiddelen BV protiv Europske komisije, ECLI:EU:C:2016:812.

${ }^{60}$ Rješenje Općeg suda u predmetu T-773/16, Salehi protiv Europske komisije, ECLI:EU:T:2017:739, par. 27.

61 Ibid., par. 29. 
akti za koje tvrdi da Komisija nije donijela ne odnose izravno na tužitelja te je stoga njegova tužba nedopuštena. ${ }^{62}$

\section{KOMPARATIVNA ISKUSTVA U SPOROVIMA ZBOG PROPUSTA DONOŠENJA PLANOVA ZA POBOLJŠANJE KVALITETE ZRAKA}

\subsection{Austrija ${ }^{63}$}

Republika Austrija savezna je republika, a u svakoj od devet saveznih pokrajina, sukladno § 9a. Zakona o zaštiti od imisija štetnih tvari putem zraka (Immissionsschutzgesetz - Luft, ${ }^{64} \mathrm{u}$ daljnjem tekstu: IG-L) nadležno tijelo ima obvezu donijeti program za poboljšanje kvalitete zraka, koji se prema članku 23. Direktive 2008/50/EZ o kvaliteti zraka i čišćem zraku za Europu naziva plan. U tom programu određuju se mjere koje se moraju poduzeti u slučaju prekoračenja graničnih vrijednosti. Dakle, kada dođe do prekoračenja graničnih vrijednosti, nadležno tijelo mora narediti provedbu mjera iz tog programa koje smatra potrebnim kako bi razdoblje prekoračenja bilo što je moguće kraće ( $\S 10$. do 13. IG-L-a). Nadležno tijelo to čini u obliku uredbe, što je akt izvršnog tijela za provedbu zakona, a u austrijskom upravnom pravu ne postoji pravo zahtijevati da se donese uredba. Usprkos tome, pojedinci i udruge za zaštitu okoliša pokušavali su pred austrijskim sudovima postići primjenu standarda kvalitete zraka, a sve do 2015. godine takvi pokušaji bili su bez uspjeha. ${ }^{65}$ Međutim, kao posljedica presude SEU-a u predmetu Janecek, austrijski Upravni sud u svibnju 2015. donio je presudu u kojoj je utvrdio da pojedinci mogu podnijeti tužbu kojom zahtijevaju da se donese uredba s mjerama za poboljšanje kvalitete zraka. ${ }^{66} \mathrm{~S}$ druge strane, ako nadležno tijelo smatra da granične vrijednosti nisu prekoračene, mora i u tom slučaju donijeti odluku koja se može pobijati pred upravnim sudovima u okviru postojećih pravnih sredstava.

Zbog prakse Suda EU-a u vezi sa zaštitom zraka od onečišćenja, austrijski zakonodavac odlučio je izmijeniti IG-L u koji je uveo određena pravna sredstva za pojedince i udruge za zaštitu okoliša. Stoga zaključujemo da se u Austriji pravo podnošenja zahtjeva za donošenje uredbe primjenjuje samo u kontekstu zaštite od onečišćenja zraka, a sukladno novim odredbama IG-L-a (§ 9a. (11)).

62 Ibid., par. 30 .

63 Podaci o austrijskom zakonodavstvu i sudskoj praksi prikupljeni su od Univ. Prof. Dr. Verene Madner (podaci će biti javno objavljeni na web-stranici avosetta.org).

${ }_{64}$ Bundesgesetz zum Schutz vor Immissionen durch Luftschadstoffe, BGB1. I Nr. 115/1997, posljednja izmjena BGB1. I Nr. 73/2018.

65 V. primjerice, Verwaltungsgerichtshof (VwGH), 2010/07/0161, 26. VI. 2012.

66 VwGH, Ro 2014/07/0096, 28. V. 2015. 


\section{2. Češka ${ }^{67}$}

U Češkoj je pristup bio drugačiji od onog opisanog u Austriji. Člankom 82. Zakona o upravnom sudstvu ${ }^{68}$ uređen je postupak u vezi sa zaštitom od nezakonitog postupanja, upute ili izvršenja (u daljnjem tekstu: postupanje) upravnih tijela. Sukladno tom članku, svatko tko smatra da se na njega izravno odnosi ili utječe nezakonitim postupanjem, uputom ili izvršenjem upravnih tijela, koje nije odluka, ima pravo podnijeti tužbu za zaštitu ili za utvrđenje da je takvo postupanje nezakonito. U tom smislu, sudska zaštita pruža se u slučajevima u kojima tužitelj može što preciznije odrediti što smatra nezakonitim miješanjem te da postoji izravna veza između nezakonitog miješanja, koje se može očitovati i kao propuštanje postupanja, i nezakonite posljedice u obliku nezakonite situacije. U pogledu prekoračenja graničnih vrijednosti, nezakonita je posljedica odnosno situacija onečišćenje zraka.

U jednom relevantnom slučaju podnesena je tužba protiv regionalnog tijela Moravsko-šleske pokrajine zbog propusta donošenja akcijskog plana za poboljšanje kvalitete zraka temeljem spomenutog članka 82. Zakona o upravnom sudstvu. Nezakonitim postupanjem, odnosno propuštanjem postupanja, smatrao se propust tuženika da, usprkos pogoršanju kvalitete zraka, izradi i donese akcijski plan sukladno tadašnjem članku 7. Zakona br. 86/2002 o zaštiti zraka ${ }^{69}$ za područja u kojima je došlo do onečišćenja (gradski okruzi Ostrava Radvanice and Bartovice). Vrhovni upravni sud presudio je temeljem presuda Suda EU-a u predmetima C-237/07 Janecek i C-404/13 ClientEarth ${ }^{70}$ te utvrdio da se mora donijeti akcijski plan sukladno Zakonu br. 86/2002. Presudio je da regionalno tijelo nije ispunilo svoju dužnost te je time došlo do nezakonitog postupanja. ${ }^{71}$

Iz analize ovog predmeta proizlazi da je u Češkoj moguće podnijeti tužbu zbog nezakonitog postupanja, što uključuje i propuštanje postupanja, u slučaju nedonošenja akcijskog plana kao općeg akta. Tužbe temeljem članka 82. Zakona o upravnom sudstvu nisu ograničene samo na slučajeve vezane uz zaštitu zraka. U teoriji, moguće je podnijeti tužbu i u drugim slučajevima ako su ispunjene pretpostavke iz članka 82., pogotovo kada je riječ o planovima i programima čija je obveza donošenja propisana pravom EU-a.

67 Podaci o češkom zakonodavstvu i sudskoj praksi prikupljeni su od doc. JUDr. Ilone Jančářová, Masarykova univerzita (podaci će biti javno objavljeni na web-stranici avosetta.org).

68 Zákon č. 150/2002 Sb., soudní řád správní.

69 Zákon č. 86/2002 Sb., zákon o ochraně ovzduší.

70 Presuda Suda u predmetu C-404/13 ClientEarth, ECLI:EU:C:2014:2382. Ovdje je riječ bila o tome da je Velika Britanija donijela plan za poboljšanje kvalitete zraka, ali je u njemu predvidjela da će se $u$ nekim zonama kvaliteta zraka uskladiti s graničnim vrijednostima tek 2025 . godine. Visoki sud u Londonu je, temeljem presude Suda Europske unije u predmetu C-404/13, naredio Vladi Velike Britanije da donese novi poboljšani plan u roku od 8 mjeseci jer dosadašnji plan nije predviđao dovoljno učinkovite mjere koje će dovesti do usklađenja s graničnim vrijednostima što je prije moguće.

71 Nejvyšší správní soud, 2 As 48/2015 - 60, 11. VI. 2015. 


\subsection{Francuska}

U lipnju i kolovozu 2015., udruga Les Amis de la Terre zatražila je od predsjednika Republike, premijera i ministara nadležnih za okoliš da, između ostalog, izrade jedan ili više planova za poboljšanje kvalitete zraka u kojima bi se odredile odgovarajuće mjere za smanjenje koncentracija lebdećih čestica i dušičnog dioksida u pojedinim zonama i aglomeracijama unutar graničnih vrijednosti utvrđenih Prilogom XI. Direktive 2008/50/EZ. S obzirom na to da nisu primili nikakav odgovor, podnijeli su tužbu zbog šutnje uprave u pogledu svojih zahtjeva koja se treba smatrati kao prešutnom odlukom o odbacivanju zahtjeva. Državni savjet je u srpnju 2017. presudio u korist tužitelja. ${ }^{72}$ Svojom je presudom poništio prešutnu odluku tuženika kojom se odbacuje zahtjev za izradu planova u skladu s člankom 23. Direktive 2008/50/EZ. Također je presudio da su tuženici dužni poduzeti sve potrebne mjere za izradu i provedbu plana za poboljšanje kvalitete zraka za pojedine zone kojima bi se postigle granične vrijednosti u najkraćem mogućem roku te dostaviti ih Europskoj komisiji do 31. ožujka 2018.

Podnošenje tužbe zbog šutnje uprave uređeno je člankom R 421-2 Zakonika o upravnom sudovanju ${ }^{73}$ koji glasi:

Ako zakonska ili podzakonska odredba ne propisuje drukčije, u slučajevima kada se šutnja upravnog tijela smatra odlukom o odbacivanju podnesenog zahtjeva, zainteresirana osoba može predmetnu odluku pobijati u roku od dva mjeseca koji se računa od datuma koji se smatra danom donošenja prešutne odluke o odbacivanju. Međutim ako izričita odluka o odbacivanju zahtjeva bude donesena prije isteka tog vremena, rok za podnošenje pravnog lijeka teče iznova od njezina donošenja.

Dan podnošenja zahtjeva upravnom tijelu, koji se može dokazati na bilo koji način, mora biti naznačen u tužbi. ${ }^{74}$

\section{TUŽBA ZBOG PROPUSTA DONOŠENJA OPĆEG AKTA U HRVATSKOM PRAVU}

Podzakonski općenormativni akti, odnosno opći akti kako ih skraćeno nazivamo u ovom radu, iznimno su važan izvor upravnog prava. Propisivanje pravila ponašanja isključivo zakonima teško je ostvarivo te je, stoga, nužno da se pojedina društvena područja uređuju i drugim propisima, osim zakona. Često se ističu dva glavna razloga potrebe da se donose podzakonski općenormativni akti. ${ }^{75}$ Kao prvi razlog navodi se da je nepraktično da zakon obuhvati sve potankosti koje se mogu pojaviti u društvenom području koje njegov tekst regulira. Ako bi zakonodavac htio

72 Conseil d'État, N³94254, 12 juillet 2017.

73 Code de justice administrative, Partie réglementaire - Décrets en Conseil d'Etat. Livre IV: L'introduction de l'instance de premier ressort.

74 Gjidara, M.; Britvić Vetma, B., Francusko-hrvatski upravnopravni pojmovnik, Pravni fakultet Sveučilišta u Splitu i Université Panthéon-Assas, Paris 2, Split / Paris, 2018., str. 647.

75 V. Borković, I., Upravno pravo, Narodne novine, Zagreb, 2002., str. 99-100. 
urediti sve pojedinosti, zakon bi postao preopširan, nepregledan i teško primjenjiv. Stoga, da bi se osigurali preciznost i jasnoća zakonskog teksta, nužno je da se donose i podzakonski općenormativni akti koji će udovoljiti toj potrebi detaljnijeg reguliranja društvenih odnosa. Drugi razlog kojim se objašnjava potreba donošenja podzakonskih općenormativnih akata jest stvarna nemogućnost da zakonodavno tijelo bude isključivi nositelj normativnih funkcija u državi ${ }^{76} \mathrm{i}$ da sva društvena područja budu regulirana samo zakonom.

Prema načelu zakonitosti, podzakonski općenormativni akt ne može biti donesen ako njegov donositelj nije prethodno ovlašten (nadležan) za donošenje takvog akta niti smije biti donesen u postupku koji je protivan zakonu. Osim toga, ne smije svojim sadržajem proturječiti zakonima. ${ }^{77} \mathrm{U}$ protivnom je moguće pokrenuti postupak ocjene njegove zakonitosti pred Visokim upravnim sudom, ako je riječ o općim aktima jedinice lokalne i područne (regionalne) samouprave, pravne osobe koja ima javnu ovlast i pravne osobe koja obavlja javnu službu, odnosno pred Ustavnim sudom, ako je riječ o općim aktima („,drugim propisima”) tijela državne vlasti i, iznimno, statutima jedinica lokalne i područne (regionalne) samouprave. ${ }^{78}$ Postoje i drugi oblici kontrole nad zakonitosti općih akata, pored njihova objektivnog stavljanja izvan snage. ${ }^{79}$

Međutim, ako nadležno tijelo nije ispunilo svoju zakonsku obvezu te je propustilo donijeti opći akt koji je bilo dužno donijeti, ne postoji neka posebna tužba ili zahtjev koji bi se, specifično baš za tu nezakonitu situaciju, mogao podnijeti. O učestalosti nedonošenja podzakonskih propisa u zakonom određenom roku Ustavni sud izvijestio je Hrvatski sabor još 2005. godine u izvješću (U-X-835/2005 od 24. veljače 2005.) donesenom na temelju ustavne ovlasti da prati ostvarivanje ustavnosti i zakonitosti te o uočenim pojavama neustavnosti i nezakonitosti izvješćuje Hrvatski sabor:

Ustavnom sudu podnesen je veći broj prijedloga za ocjenu ustavnosti $i$ zakonitosti drugih (podzakonskih) propisa koji su doneseni nakon proteka zakonom određenog roka za njihovo donořenje. Predlagatelj smatra da je protekom roka za donošenje podzakonskog propisa prestalo ovlaštenje donositelja za donošenje takvog propisa te predlaže Ustavnom sudu da takve propise ukine zbog njihove nesuglasnosti s odredbama članka 5. stavka 2. i članka 14. stavka 2. Ustava. Ustavni sud je razloge za neprihvaćanje prijedloga podrobno obrazložio u Rješenju broj: U-II-4343/2004 od 24. veljače 2005. godine.

U obrazloženju navedenog rješenja Ustavni sud je utvrdio da je sporni podzakonski akt donesen nakon zakonom određenog roka za njegovo donošenje. Ustavni sud je, međutim, zauzeo stajalište da razlozi pravne sigurnosti objektivnog pravnog poretka, podrobno obrazloženi u točki 4. obrazloženja navedenog rješenja, pretežu nad zahtjevom za ukidanjem osporenog podzakonskog akta.

\footnotetext{
76 Ivančević, V., Institucije upravnog prava, op. cit., str. 87.

77 Borković, I., op. cit., str. 70.

78 V. Rješenje Ustavnog suda, U-II-5157/2005 od 5. ožujka 2012.

79 Borković, I., op. cit., str. 105-109.
} 
Ustavni sud upozorava da se podzakonski propisi često donose nakon proteka zakonom određenog roka za njihovo donošenje, a što nije u skladu s načelom ustavnosti $i$ zakonitosti, pa o toj pojavi izvješćuje Hrvatski sabor. ${ }^{80}$

Dodatno, Ustav u članku 125.a odnosno članku 130. prema pročišćenom tekstu ${ }^{81}$ propisuje da Ustavni sud, ako utvrdi da nadležno tijelo nije donijelo propis za izvršenje odredaba Ustava, zakona i drugih propisa, a bilo je dužno takav propis donijeti, o tome obavještava Vladu, a o propisima koje je bila dužna donijeti Vlada, obavještava Hrvatski sabor. Dosad se Ustavni sud samo tri puta poslužio tom svojom nadležnošću:

(1) Izvješće o utvrđenom propustu ministra zdravlja da donese propis o načinu prikupljanja medicinske dokumentacije te utvrđivanju uvjeta i pretpostavki za promjenu spola i života u drugom rodnom identitetu, broj: U-XA$1367 / 2014$ od 9 . travnja 2014; ${ }^{82}$

(2) Izvješće o nedonošenju propisa o posebnoj vrsti naknade za pokretnine oduzete za vrijeme jugoslavenske komunističke vladavine, propisane člankom 48. stavkom 2. Zakona o naknadi za imovinu oduzetu za vrijeme jugoslavenske komunističke vladavine, U-XA-1842/2014 od 12. lipnja $2014 ;^{83}$

(3) Izvješće o utvrđenom propustu ministra znanosti i obrazovanja da donese propis za izvršenje zakona, U-XA-6895/2014 od 12. rujna $2017 .{ }^{84}$

Budući da je samo u prvom slučaju ministar, nakon objave izvješća Ustavnog suda, donio pravilnik koji je - sukladno zakonu - trebao donijeti, smatramo da izvješća ne postižu učinak kakav bi trebala. Ni izvješće Ustavnog suda iz 2005. u kojem je upozorio da se podzakonski propisi često donose nakon proteka zakonom određenog roka za njihovo donošenje nije potaklo ažurnost donositelja. Osim toga, iz prakse primjene članka 125.a Ustava vidljivo je da se Ustavni sud rijetko koristi tom svojom nadležnošću te da je primjenjuje jedino u odnosu na nedonošenje „drugih propisa” državnih (izvršnih) tijela, a ne kad je riječ o nedonošenju općih akata drugih donositelja.

U praksi upravnih sudova u Hrvatskoj dosad nije bilo slučajeva izravnih tužbi zbog propusta donošenja općih akata. U slučaju da je riječ o novom uređenju nekog

\footnotetext{
t. III.

80 Izvješće o uočenim pojavama neustavnosti i nezakonitosti br. U-X-835/2005 od 24. veljače 2005.,

81 NN br. 85/2010.

82 Pravilnik o načinu prikupljanja medicinske dokumentacije te utvrđivanju uvjeta i pretpostavki za promjenu spola ili o životu u drugom rodnom identitetu donesen je 29. rujna 2014., a objavljen je u NN br. 132/2014, 12. studenog 2014.

83 Vlada ni nakon donošenja izvješća Ustavnog suda nije donijela uredbu sukladno članku 48. stavku 2. Zakona o naknadi. Ustavni sud je u svom izvješću istaknuo da je ovlaštenicima povrata odnosno naknade odlukama nadležnih tijela načelno priznato pravo na naknadu za pokretnine na koje se odnosi članak 48. stavak 2. Zakona o naknadi, pri čemu nisu određeni ni visina ni način isplate te naknade, tako da do njezine stvarne isplate nikada nije došlo niti je moglo doći. Taj propis ni danas nije donesen, iako je od stupanja na snagu Zakona o naknadi proteklo više od 22 godine.

${ }_{84}$ Riječ je o Pravilniku o priznavanju i vrednovanju neformalnog i informalnog učenja. On još uvijek nije donesen.
} 
područja koje je već bilo regulirano postojećim zakonom, zakonodavac se u pravilu koristi metodom da produži važenje provedbenih propisa i drugih općih akata koji su doneseni na temelju zakona koji prestaje važiti, do donošenja novih. Ujedno, zbog načela zakonitosti, u pravilu se propisuje da dotadašnji provedbeni propisi/opći akti ostaju na snazi samo u onim dijelovima u kojima nisu u suprotnosti s odredbama novog zakona. Ako u takvim situacijama dođe do problema neusklađenosti novog zakona sa starim provedbenim propisima/općim aktima, u konkretnim slučajevima mora se primijeniti izravno novi zakon, a ne stari provedbeni propis/opći akt jer on nije sukladan važećem zakonu.

Međutim, kada je riječ o nekom pravnom području koje se prvi put regulira ili se regulira na sasvim nov način, pa ne postoji provedbeni propis/opći akt kojem bi se produljilo važenje do stupanja na snagu novog koji se tek treba donijeti, propust donošenja provedbenog propisa/općeg akta može dovesti do situacije da je praktički spriječena primjena zakona, a strankama onemogućeno ostvarenje njihovih prava ili pravnih interesa. Osim toga, time su povrijeđena i načela pravne predvidljivosti, pravne sigurnosti i pravne izvjesnosti odnosno vladavina prava kao jedna od najviših vrednota ustavnog poretka Republike Hrvatske (članak 3. Ustava).

Kao što je prikazano u uvodu ovog rada, potreba za omogućavanjem sudske zaštite zbog propusta donošenja općeg akta može proizlaziti iz prava Europske unije. U nastavku rada razmotrit ćemo mogu li se u takvim slučajevima primijeniti postojeće odredbe ZUS-a i jesu li one dostatne za rješavanje pitanja koja se mogu pojaviti u tijeku postupka.

Sukladno članku 3. stavku 1. ZUS-a predmet upravnog spora jesu:

1. ocjena zakonitosti pojedinačne odluke kojom je javnopravno tijelo odlučilo o pravu, obvezi ili pravnom interesu stranke u upravnoj stvari (upravni akt) protiv koje nije dopušteno izjaviti redoviti pravni lijek,

2. ocjena zakonitosti postupanja javnopravnog tijela iz područja upravnog prava kojim je povrijeđeno pravo, obveza ili pravni interes stranke protiv kojeg nije dopušteno izjaviti redoviti pravni lijek,

3. ocjena zakonitosti propuštanja javnopravnog tijela iz područja upravnog prava da u zakonom propisanom roku odluči o pravu, obvezi ili pravnom interesu ili redovitom pravnom lijeku stranke odnosno da postupi prema propisu,

4. ocjena zakonitosti sklapanja, raskidanja i izvršavanja upravnog ugovora.

Osim toga, predmet je upravnog spora i ocjena zakonitosti općeg akta jedinice lokalne i područne (regionalne) samouprave, pravne osobe koja ima javnu ovlast i pravne osobe koja obavlja javnu službu (čl. 3. st. 2. ZUS-a).

Smatramo da bi se tužba zbog propusta donošenja općeg akta mogla temeljiti na odredbi čl. 3. st. 1.t. 3. sukladno kojoj predmet upravnog spora može biti ocjena zakonitosti propuštanja javnopravnog tijela iz područja upravnog prava da postupi prema propisu. Tužitelj bi u tom slučaju tužbom mogao zahtijevati postupanje koje je tuženik sukladno propisima obvezan izvršiti (čl. 22. st. 2. t. 3. ZUS-a). Postupanje 
koje bi se tužbom tražilo odnosilo bi se na donošenje općeg akta koje je tuženik propustio donijeti sukladno zakonu.

Međutim, budući da će sud rješenjem odbaciti tužbu, jer ne postoje pretpostavke za vođenje spora, ako utvrdi da protiv pojedinačne odluke, postupanja ili upravnog ugovora nije iskorišten redovit pravni lijek (čl. 30. st. 1. t. 3. ZUS-a), nužno je razmotriti način na koji bi tužitelji trebali postupiti sukladno Zakonu o općem upravnom postupku ${ }^{85}$ (dalje u tekstu: ZUP) prije podnošenja tužbe. U tom pogledu od pomoći će biti usporedba s tužbom zbog propuštanja postupanja prema Ugovoru o funkcioniranju EU-a analizirana u poglavlju 2. ovog rada.

\subsection{Postupak zbog propusta donošenja općeg akta}

Glavni preduvjet za pokretanje postupka pred SEU-om zbog propuštanja postupanja jest prethodni poziv tijelu na postupanje. Smatramo da se takav prethodni poziv treba uputiti i prema ZUP-u, pa je potrebno sagledati je li moguće i na koji način primijeniti njegove odredbe prije podnošenja tužbe upravnom sudu. ${ }^{86}$

Prethodni poziv tijelu na donošenje općeg akta koje nije donijelo mogao bi se temeljiti na članku 156. ZUP-a koji propisuje da osoba koja smatra da joj je drugim postupanjem javnopravnog tijela iz područja upravnog prava, o kojem se ne donosi rješenje, povrijeđeno pravo, obveza ili pravni interes, može izjaviti prigovor sve dok takvo postupanje traje ili traju njegove posljedice. Đerđa pojašnjava da je ovdje riječ o svim ostalim interakcijama u koje javnopravna tijela i građani dolaze, a koje proizlaze iz poslova javne uprave koji su joj povjereni zakonom, pa se ova zaštita može nazvati i „općom supsidijarnom zaštitom“ koju će osoba moći koristiti kada joj ni jedno drugo pravno sredstvo ne stoji na raspolaganju ${ }^{87}$ To znači da bi se poziv na donošenje općeg akta podnosio u obliku prigovora u kojem bi se naveo opći akt koji je sukladno zakonu trebao biti donesen, a tijelo ga je propustilo donijeti. Iako članak 156. izrijekom navodi postupanje, prava, obveze ili pravni interesi neke osobe mogu biti povrijeđeni i nepostupanjem, stoga smatramo da se ovaj članak može primijeniti i u slučaju propusta postupanja odnosno propusta donošenja općeg akta.

Prigovor bi u tom smislu bila ovlaštena podnijeti fizička ili pravna osoba, ili skupina osoba povezanih zajedničkim interesom (bez pravne osobnosti), na čija prava, obveze ili pravne interese nedonošenje općeg akta izravno utječe jer bi se taj opći akt primjenjivao na nju bilo neposredno, bilo putem donošenja pojedinačnih akata koji bi se temeljio na tom općem aktu koji nije donesen. Također, vezano za

$85 \mathrm{NN}$ br. 47/2009.

86 ZUP-om je prošireno područje njegove primjene u odnosu na njegova prethodnika (Zakon o općem upravnom postupku, NN br. 53/1991 i 103/1996 - Odluka Ustavnog suda RH). Tri nova područja jesu upravni ugovori, druga postupanja javnopravnih tijela i zaštita prava i pravnih interesa stranaka od nezakonitog ili nepravilnog rada pravnih osoba koje obavljaju javne službe. V. Medvedović, D., „Utjecaj Zakona o općem upravnom postupku i Zakona o upravnim sporovima na novo zakonodavstvo“, u: Gagro, B. et al., ZUP - iskustva u praksi i primjeri, Novi informator, Zagreb, 2011., str. 23.

87 Đerđa, D., Opći upravni postupak u Republici Hrvatskoj, Inženjerski biro, Zagreb, 2010., str. 345. 
utvrđivanje pravnog interesa, upravni sudovi morali bi uzeti u obzir presude Suda EU-a u postupcima koji se odnose na prethodna pitanja (primjerice, spomenute presude u predmetima C-237/07 Janecek i C-404/13 ClientEarth).

Što se tiče forme prigovora, on je propisan u članku 122. stavku 2. ZUP-a, sukladno kojemu se odredbe o obliku, sadržaju i predaji žalbe na odgovarajući način primjenjuju i na prigovor. Prigovor se može podnijeti poput svakog podneska neposredno u pisanom obliku, poslati poštom, dostaviti u obliku elektroničke isprave izrađene sukladno zakonu ili usmeno izjaviti na zapisnik (čl. 71. st. 3. ZUP-a). U pogledu sadržaja, podnositelj prigovora mora navesti postupanje u odnosu na koje podnosi prigovor, što znači da treba jasno naznačiti o kojem općem aktu je riječ koje je tijelo propustilo donijeti (čl. 108. st. 1. u vezi s čl. 122. st. 2. ZUP-a). Podnositelj prigovora trebao bi navesti i zbog čega je nezadovoljan nedonošenjem općeg akta, odnosno na koji način takav propust negativno utječe na njegova prava, obveze ili pravni interes. Prigovor u svakom slučaju mora biti razumljiv i sadržavati sve što je potrebno da bi se po njemu moglo postupiti, a osobito naziv javnopravnog tijela kojem se upućuje, osobno ime (ime i prezime) podnositelja, odnosno osobe ovlaštene za zastupanje ako je podnositelj ima, i adresu te osobe (čl. 71. st. 2. ZUP-a). Podnositelj mora potpisati prigovor, odnosno osoba ovlaštena za zastupanje u slučaju da je ima (čl. 71. st. 5. ZUP-a).

Prigovor se izjavljuje čelniku tijela (čl. 122. st. 1. ZUP-a). Čak i ako čelnik tijela nije ovlašteni donositelj općeg akta, ne smatramo da je odredba da se prigovor izjavljuje njemu, a ne izravno tijelu koje je trebalo donijeti opći akt (primjerice, gradskom vijeću, županijskoj skupštini ili nekom kolegijalnom tijelu u okviru pravne osobe s javnim ovlastima) neprikladna, budući da su čelnici ovlašteni pripremati prijedloge općih akata ili sazivati sjednice odgovarajućih tijela te predlagati dnevni red.

Sljedeće pitanje koje se postavlja jest u kojem je roku potrebno podnijeti prigovor i zatražiti donošenje općeg akta. U pravilu se zakonskom odredbom kojom se nalaže donošenje nekog općeg akta ujedno propisuje u kojem se roku akt treba donijeti. Često je riječ o dugim rokovima (primjerice, šest mjeseci, godinu dana, dvije godine) koji se računaju od dana stupanja na snagu zakona koji propisuje njihovo donošenje. Smatramo da su to dilatorni rokovi koji odgađaju poduzimanje određene radnje (odnosno podnošenje prigovora zbog propusta donošenja općeg akta), što znači da je prije njihova isteka podnošenje prigovora preuranjeno. Ako nikakav rok nije propisan, propustom ili omaškom zakonodavca, smatramo da bi se vrijeme njegova trajanja trebalo izvesti iz teleološke interpretacije zakona. No takav propust zakonodavca, ako se dogodi, značajno otežava situaciju za podnositelja prigovora, s obzirom na to da se nalazi u neizvjesnosti je li dovoljno vremena prošlo da se može smatrati da je rok za donošenje općeg akta protekao.

Trajanje roka za podnošenje prigovora nije propisano u danima već se prigovor može podnijeti sve dok propuštanje postupanja traje ili dok traju njegove posljedice. Mišljenja smo da prigovor ne može biti zakašnjeli. Ako opći akt nije donesen u 
propisanom roku, podnositelj ne može zakasniti s podnošenjem prigovora jer je riječ o povredi koja traje.

Rok za odgovor na prigovor vrlo je kratak. Naime, sukladno članku 122. stavku 3. ZUP-a čelnik tijela odlučuje o prigovoru rješenjem u roku od osam dana od dana izjavljivanja prigovora. Usporedbe radi, rok prema članku 265. stavku 2. UFEU-a iznosi dva mjeseca. Za očekivati je da zbog tako kratkog roka za rješavanje prigovora, u većini slučajeva neće se moći opći akt i donijeti, što znači da će povreda zakona i dalje trajati. Čak i ako u rješenju kojim se prigovor rješava bude navedeno da se donošenje općeg akta planira u nekom narednom razdoblju, smatramo da bi podnositelj i na takvo rješenje o prigovoru imao pravo podnijeti pravni lijek ako opći akt nije još donesen. Mišljenja smo da jedino donošenje općeg akta može dovesti do okončanja postupka zbog propusta. Osim toga, ako opći akt ne bi bio donesen ni u nekom dodatnom roku koji bi samo javnopravno tijelo dodijelilo, podnositelj bi ponovno morao podnijeti prigovor zbog propusta donošenja općega akta jer bi mu rok za podnošenje pravnog lijeka protiv donesenog rješenja o prethodnom prigovoru već odavno istekao.

U pojedinim situacijama može se još dogoditi da javnopravno tijelo nije donijelo opći akt zbog okolnosti na koje nema utjecaja. To će biti slučaj u situaciji kada je za donošenje općeg akta jednog donositelja potrebna suglasnost nekog drugog javnopravnog tijela, a bez te suglasnosti akt ne može stupiti na snagu. Problem se javlja kada je opći akt donesen, ali to drugo tijelo propušta donijeti suglasnost i praktički onemogućuje njegovo stupanje na snagu. Smatramo da u tom slučaju donositelj općeg akta ne bi trebao biti tuženik, jer se njemu ne može prigovoriti nezakonito nepostupanje.

\section{2. Žalbeni postupak}

Sukladno članku 122. stavku 5. ZUP-a, protiv rješenja prvostupanjskog tijela o prigovoru može se izjaviti žalba, a protiv rješenja drugostupanjskog tijela o prigovoru može se pokrenuti upravni spor. Ako nema drugostupanjskog tijela, protiv rješenja tijela o prigovoru može se pokrenuti upravni spor.

U slučaju da postoji drugostupanjsko tijelo, žalbeni postupak koji bi se također morao iscrpiti prije podnošenja tužbe upravnom sudu smatramo neprimjerenim. Nema puno smisla da tuženik u upravnom sporu bude tijelo koje uopće nije ovlašteni donositelj općeg akta. Bilo bi prikladnije da se takav žalbeni postupak jednostavno isključi kao preduvjet za podnošenje tužbe. Naime, čak i da se usvoji žalba izjavljena protiv rješenja o prigovoru i da drugostupanjsko tijelo naredi prvostupanjskom tijelu donošenje općeg akta, problematično je kako bi se osiguralo prisilno izvršenje tog rješenja u slučaju da prvostupanjsko tijelo ne donese opći akt ni nakon usvajanja žalbe. Podnositelj bi zapravo ponovno morao podnijeti prigovor zbog propusta postupanja odnosno zbog propusta donošenja općeg akta, a drugostupanjsko tijelo nema ovlast donijeti opći akt umjesto onog tijela koje ga je trebalo donijeti. 


\subsection{Postupak pred upravnim sudom}

\subsubsection{Tužitelj}

Tužitelj u upravnom sporu zbog propusta donošenja općeg akta, sukladno odredbi članka 17. stavka 1. ZUS-a, fizička je ili pravna osoba koja smatra da su joj prava i pravni interesi povrijeđeni pojedinačnom odlukom, postupanjem javnopravnog tijela, odnosno propuštanjem donošenja pojedinačne odluke ili postupanja javnopravnog tijela u zakonom propisanom roku. Također, tužitelj može biti osoba koja nema pravne osobnosti ili skupina osoba ako smatraju da su pojedinačnom odlukom ili postupanjem javnopravnog tijela odnosno propuštanjem donošenja pojedinačne odluke ili postupanja javnopravnog tijela povrijeđena njihova prava i pravni interesi (čl. 17. st. 2. ZUS-a) ${ }^{88}$

Već smo naveli (v. 5.1.) da su ovlašteni podnositelji prigovora one osobe na čija prava, obveze ili pravne interese nedonošenje općeg akta izravno utječe. Dodali bismo još da, kada je riječ o općim aktima koji se odnose na okoliš, sukladno Konvenciji o pristupu informacijama, sudjelovanju javnosti u odlučivanju i pristupu pravosuđu u pitanjima okoliša ${ }^{89}$ nevladine organizacije koje rade na promicanju zaštite okoliša i udovoljavaju svim zahtjevima domaćeg zakonodavstva smatraju se „zainteresiranom javnosti“ kojoj bi se trebao omogućiti pristup pravosuđu u pitanjima okoliša.

\subsubsection{Tuženik}

Smatramo da bi tuženik trebalo biti ono javnopravno tijelo koje je propustilo donijeti opći akt u propisanom roku. No, kao što smo već pojasnili (v. 5.2.), ako postoji drugostupanjsko tijelo, ono će biti tuženik, a ne prvostupanjsko tijelo. Postavlja se pitanje ima li drugostupanjsko tijelo dovoljno ,jake“ ovlasti kojima bi moglo osigurati da prvostupanjsko tijelo donese opći akt koji je trebalo donijeti te bi li se odredba članka 81. stavka 1. ZUS-a sukladno kojoj je izvršenje presude dužan osigurati tuženik, odnosno tijelo nadležno za izvršenje, mogla protumačiti da je ,tijelo nadležno za izvršenje“" zapravo prvostupanjsko tijelo. ${ }^{90}$ Kada je riječ o sporovima zbog propusta donošenja općih akata čija obveza donošenja proizlazi iz odredbi prava EU-a, takvo tumačenje osiguralo bi djelotvorno ostvarenje prava dodijeljenih pravom Unije.

88 Premda je u odredbi članka 17. stavka 2. ZUS-a propisan uvjet da su takvim tužiteljima pojedinačnom odlukom ili postupanjem javnopravnog tijela povrijeđena njihova prava i pravni interesi, Đerđa i Šikić pojašnjavaju da je, kao i za osobe u stavku 1., dostatno da smatraju da su im povrijeđena prava i pravni interesi - Đerđa, D., Šikić, M., Komentar Zakona o upravnim sporovima, Novi informator, Zagreb, 2012., str. 132. S takvim stajalištem u potpunosti se slažemo. Također bismo dodali da se tužba može podnijeti i zbog nepostupanja, iako to nije izrijekom navedeno u stavku 2.

89 NN - MU br. 1/2007.

90 V. Staničić, F., Britvić Vetma, B., Horvat, B., Komentar Zakona o upravnim sporovima, Narodne novine, Zagreb, 2017., str. 271. 


\subsubsection{Rok za podnošenje tužbe}

Rokova za tužbu može biti nekoliko, ovisno o tome kako je prigovor riješen. Ako je prigovor odbačen ili odbijen, ili je žalba protiv prigovora odbačena ili odbijena, rok za podnošenje tužbe teče od dana dostave rješenja i iznosi 30 dana. Ako je prigovor usvojen, ali opći akt nije donesen već će tek u budućnosti biti donesen, povreda zakonske obveze donošenja općeg akta i dalje traje. Smatramo da i u tom slučaju tužitelj može podnijeti tužbu u roku od 30 dana od dana dostave rješenja o prigovoru, pod uvjetom da nema drugostupanjskog tijela kojem bi se prije podnošenja tužbe morala podnijeti žalba.

Ako o prigovoru nije odlučeno u roku od osam dana, a ne postoji drugostupanjsko tijelo, tada se tužba može podnijeti najranije osam dana nakon proteka tog roka (čl. 24. st. 2. ZUS-a). Takva tužba jedino može biti preuranjena, ali ne može biti zakašnjela dok šutnja tj. propuštanje donošenja rješenja o prigovoru traje.

Ako postoji drugostupanjsko tijelo, potrebno je prije podnošenja tužbe inicirati žalbeni postupak. Drugostupanjsko tijelo o žalbi mora odlučiti najkasnije u roku od 60 dana od dana predaje uredne žalbe (čl. 121. ZUP-a). Ako protekne rok, a o žalbi nije odlučeno, može se pokrenuti upravni spor. I tada se tužba može podnijeti najranije osam dana nakon proteka tog roka (čl. 24. st. 2. ZUS-a).

\subsubsection{Usvajanje tužbenog zahtjeva}

Kod usvajanja tužbenog zahtjeva upravni sud ne može donijeti opći akt umjesto javnopravnog tijela koje ga je propustilo donijeti. Upravni sud, ako utvrdi da tuženik nije postupio sukladno propisima, presudom će usvojiti tužbeni zahtjev i narediti postupanje u primjerenom roku (čl. 58. st. 4. ZUS-a). To znači da će narediti donošenje općeg akta u primjerenom roku. Ovisno o složenosti sadržaja općeg akta, primjereni rok može iznositi od dva mjeseca do više mjeseci. Smatramo da rok ne bi smio iznositi više od onog koliki je bio zakonski rok koji je tijelo povrijedilo odnosno da bi u svakom slučaju rok morao biti kraći od tog zakonskog roka. U protivnom bi se taj zakonski rok praktički obezvrijedio.

Posebno pitanje postavlja se o kakvom bi usvajanju tužbenog zahtjeva bila riječ ako je tužba podnesena zbog šutnje javnopravnog tijela da uopće odluči o prigovoru. U cilju pružanja učinkovite sudske zaštite smatramo da bi se, ako su ispunjene pretpostavke za donošenje općeg akta, trebalo narediti njegovo donošenje, bilo da je riječ bila o propustu odlučivanja o prigovoru ili propustu odlučivanja o žalbi protiv rješenja o prigovoru. Na taj način tužitelju će se omogućiti presuda čije se izvršenje može zahtijevati od suda u slučaju da se prema njoj ne postupi. Kada bi se u izreci presude jedino naložilo tuženiku da riješi prigovor ili žalbu, u slučaju neizvršavanja presude moglo bi se zahtijevati od tuženika samo takvo postupanje (rješavanje žalbe ili prigovora), a ne i donošenje općeg akta, što faktički znači da bi se prigovor ili žalba mogli odbaciti ili odbiti. U takvom slučaju i dalje opći akt ne bi bio donesen, pa bi se ponovno morao voditi upravni spor protiv negativnog rješenja. 


\subsubsection{Izvršenje presude}

Ako je presudom usvojen tužbeni zahtjev kojim je naređeno postupanje odnosno donošenje općeg akta u određenom primjerenom roku, pa takav rok protekne, a opći akt još uvijek nije donesen, tada bi tužitelj mogao zahtjevom za izvršenje od prvostupanjskog suda zahtijevati izvršenje presude (čl. 81. st. 3. ZUS-a). ${ }^{91}$ Izvršenje se provodi prema pravilima kojima je uređeno izvršenje u općem upravnom postupku (čl. 81. st. 4. ZUS-a). Sud može novčanim kaznama prisiliti javnopravno tijelo da izvrši sudsku presudu primjenom odredaba ZUP-a. ${ }^{92}$ Osim toga, odgovornoj osobi u nadležnom javnopravnom tijelu koja iz neopravdanog razloga ne postupi sukladno izreci presude, sud može izreći novčanu kaznu do visine jednomjesečne prosječne neto plaće u Republici Hrvatskoj (čl. 81. st. 8. ZUS-a). Odgovornom osobom smatra se čelnik nadležnog javnopravnog tijela (čl. 81. st. 9. ZUS-a).

\section{ZAKLJUČAK}

Dužnost omogućavanja sudske zaštite zbog propusta donošenja općeg akta u državama članicama Europske unije može proizlaziti iz prava Europske unije. Sud Europske unije u predmetu 237/07 Janecek utvrdio je da osobe koje su izravno zainteresirane moraju biti u mogućnosti zahtijevati od nadležnih nacionalnih vlasti, pod uvjetima koje određuje Direktiva o kvaliteti zraka, izradu akcijskog plana za poboljšanje kvalitete zraka, a ta obveza je podvrgnuta sudskoj kontroli. Po svojoj pravnoj prirodi ti planovi su opći akti. Iz analizirane sudske prakse iz Austrije, Češke i Francuske proizlazi zaključak da nadležni sudovi pružaju mogućnost tužbi zbog propusta donošenja planova za poboljšanje kvalitete zraka sukladno praksi Suda EU-a. U Hrvatskoj dosad nije bilo takvih sporova. Kada bi se takve tužbe ipak pojavile, smatramo da odredbe Zakona o upravnim sporovima omogućavaju njihovo podnošenje. Naime, tužbom u upravnom sporu može se zahtijevati postupanje koje je tuženik sukladno propisima obvezan izvršiti. No problem se javlja u postupku koji je potrebno provesti prije podnošenja tužbe sukladno Zakonu o općem upravnom postupku. Iz naše analize proizlazi da odredbe ZUP-a koje se odnose na zaštitu od drugih oblika postupanja javnopravnih tijela nisu sasvim prilagođene pružanju učinkovite zaštite u slučaju propusta donošenja općeg akta. Problem se osobito javlja kada, u odnosu na javnopravno tijelo koje nije donijelo opći akt, postoji drugostupanjsko tijelo kojemu se prije pokretanja upravnog spora mora izjaviti žalba. Međutim, čak i u situaciji da tuženik u upravnom sporu bude drugostupanjsko tijelo koje nije ovlašteno donijeti opći akt umjesto prvostupanjskog tijela, ako bi upravni sud svojom presudom naredio donošenje općeg akta u primjerenom roku,

91 Kao što smo već napomenuli, odredbom članka 81. stavka 1. ZUS-a sukladno kojoj je izvršenje presude dužan osigurati tuženik, odnosno tijelo nadležno za izvršenje, može se protumačiti da je „tijelo nadležno za izvršenje“ prvostupanjsko tijelo u situaciji kada je tuženik bilo drugostupanjsko tijelo koje nije ovlašteno umjesto prvostupanjskog tijela donijeti opći akt.

92 V. Staničić, F., Britvić Vetma, B., Horvat, B., op. cit., str. 274. 
izvršenje presude bilo bi dužno osigurati prvostupanjsko tijelo. Izvršenje presude na takav način osiguralo bi djelotvorno ostvarenje prava dodijeljenih pravom Unije.

\section{LAWSUIT OVER OMISSION TO PASS GENERAL ACTS IN EUROPEAN AND CROATIAN LAW}

In this paper, the way, pursuant to judgement of the European court in the case of C-237/07 Janecek, court protection can be ensured due to omissions in passing action plans for improving the quality of air which are, according to their legal nature, general acts. The first and second parts of this paper show comparative experiences from European Court practice regarding application of article 265 of the Agreement on the functioning of the European Union which prescribes court action for institutions of the Union for failure to act as in the court practice from Austria, Czech Republic and France in disputes for failing to pass plans for improving the quality of air. In the last section whether and in what way such court action for failing to pass general acts, whose obligation is derived from European Union law, can be brought before Croatian administrative court, that is in which way in that situation the existing provisions from the General Administrative Procedure Act and Administrative Dispute Act can be applied.

Key words: plans to improve the quality of air, general acts, lawsuit for omission, protection from other forms of public body action 